\title{
Benzylic Photobromination for the Synthesis of Belzutifan: Elucidation of Reaction Mechanisms Using in Situ LED-NMR
}

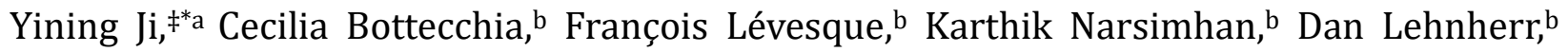

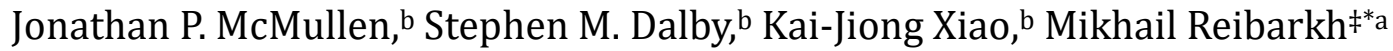

${ }^{a}$ Analytical Research and Development, Merck \& Co., Inc., Rahway, New Jersey 07065, United States

b Process Research and Development, Merck \& Co., Inc., Rahway, New Jersey 07065, United States

yining.jichen@merck.com \& $\underline{\text { mikhail reibarkh@merck.com }}$

\section{Table of Content}

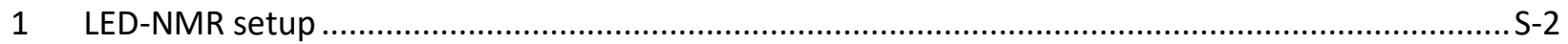

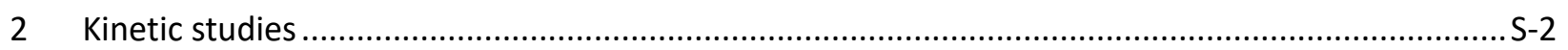

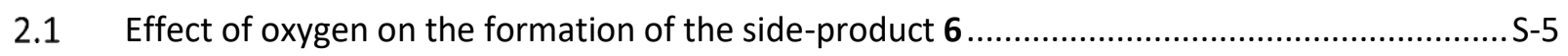

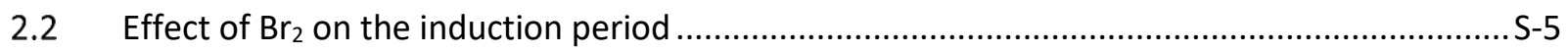

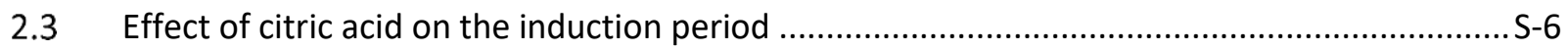

2.4 Effect of the equivalents of DBDMH 2a on the reaction performance ................................... 6

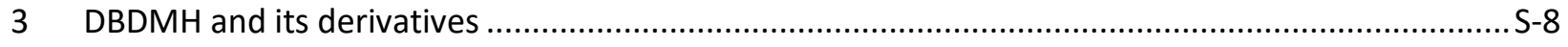

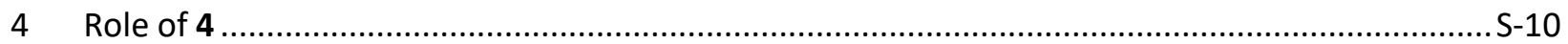

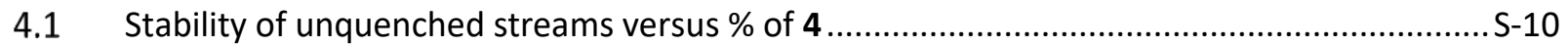

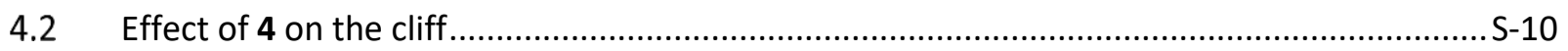

5 Citric acid mechanism of action: NMR studies with ${ }^{13} \mathrm{C}$-labeled citric acid ..................................

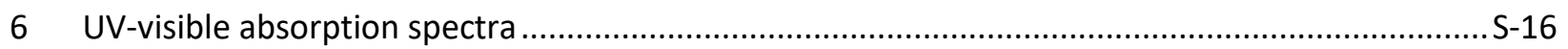

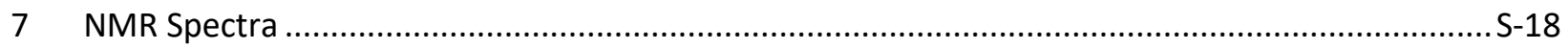




\section{LED-NMR setup}

Details of the LED-NMR setup are shown below.

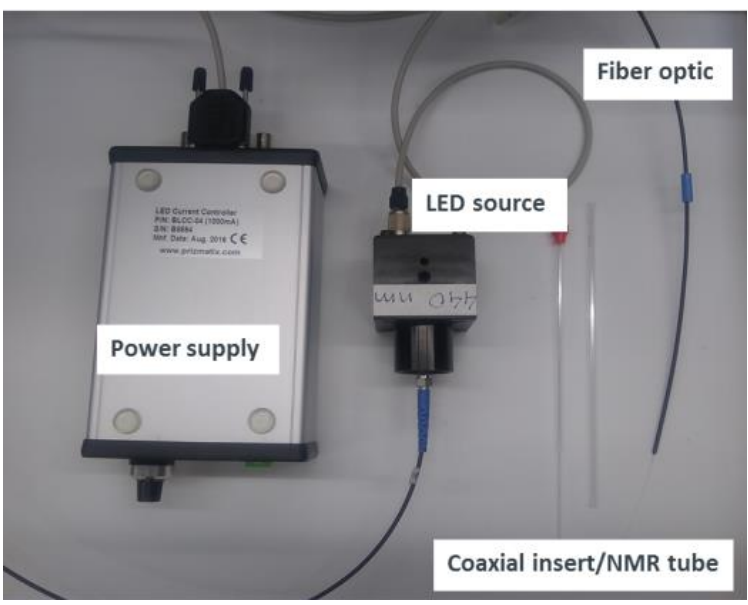

Figure S1. Illustration of the LED-NMR setup.

\section{Kinetic studies}
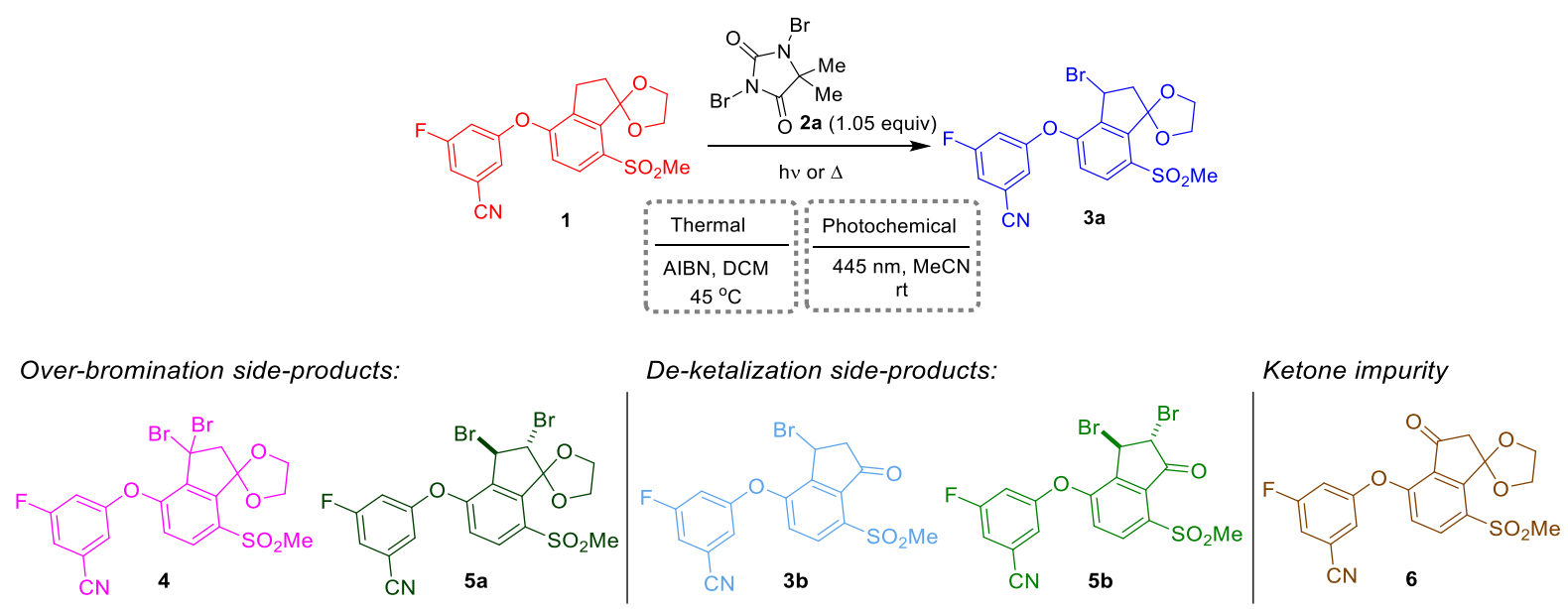

Scheme S1. Benzylic bromination of 1 under both thermal and photochemical conditions. 
Thermal bromination:
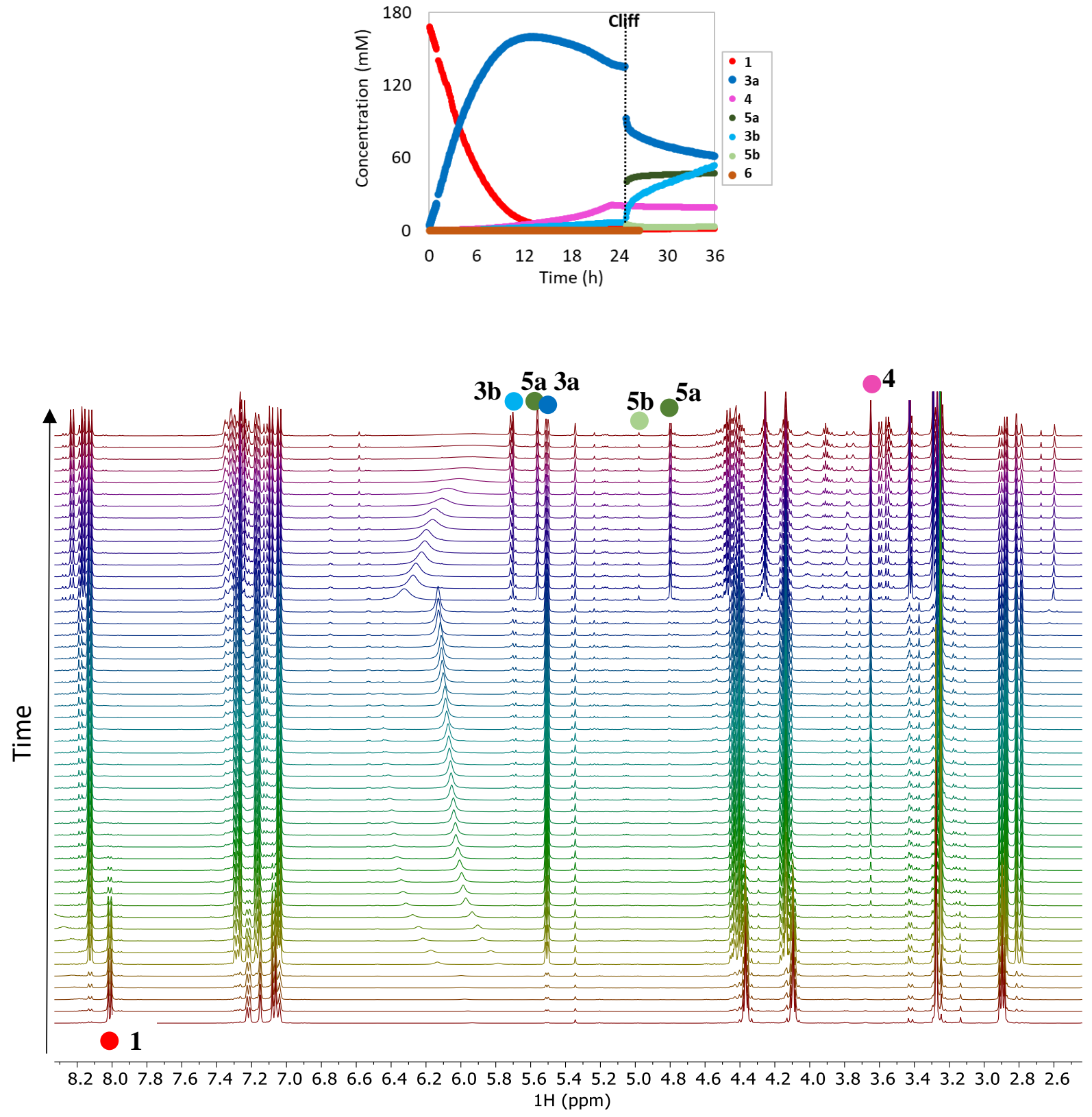

Figure S2. Temporal concentration profiles monitored by ${ }^{1} \mathrm{H}$ NMR spectroscopy of the thermal benzylic bromination using DBDMH as a brominating agent and AIBN as radical initiator. $[1]_{0}=$ $170 \mathrm{mM}, \mathrm{DBDMH}$ (1.05 equiv), AIBN (4 mol\%). The time scale of the stacked NMR spectra matches the time scale of the concentration plot. 


\section{Photochemical bromination:}
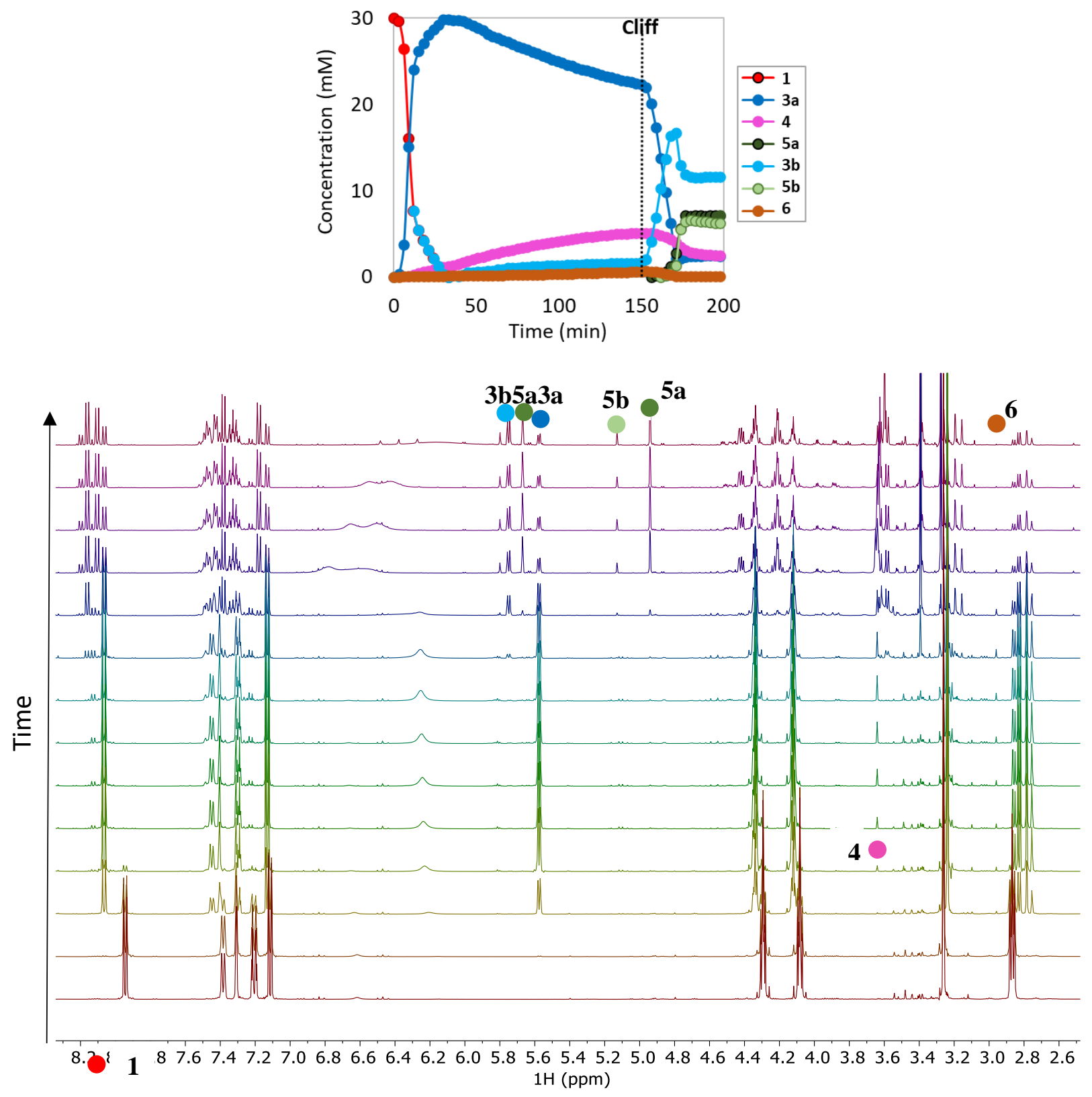

Figure S3. Temporal concentration profiles monitored by ${ }^{1} \mathrm{H}$ NMR spectroscopy of the photochemical benzylic bromination using DBDMH as a brominating agent and photons as radical initiator. $[1]_{0}=30 \mathrm{mM}$, DBDMH (1.05 equiv), $445 \mathrm{~nm}$. The time scale of the stacked NMR spectra matches the time scale of the concentration plot. 


\subsection{Effect of oxygen on the formation of the side-product 6}

Under irradiation conditions, the competitive benzylic oxidation that yields the undesired sideproduct 6 was minimized with rigorous oxygen exclusion (sample preparation inside an $\mathrm{N}_{2}$-filled glovebox).
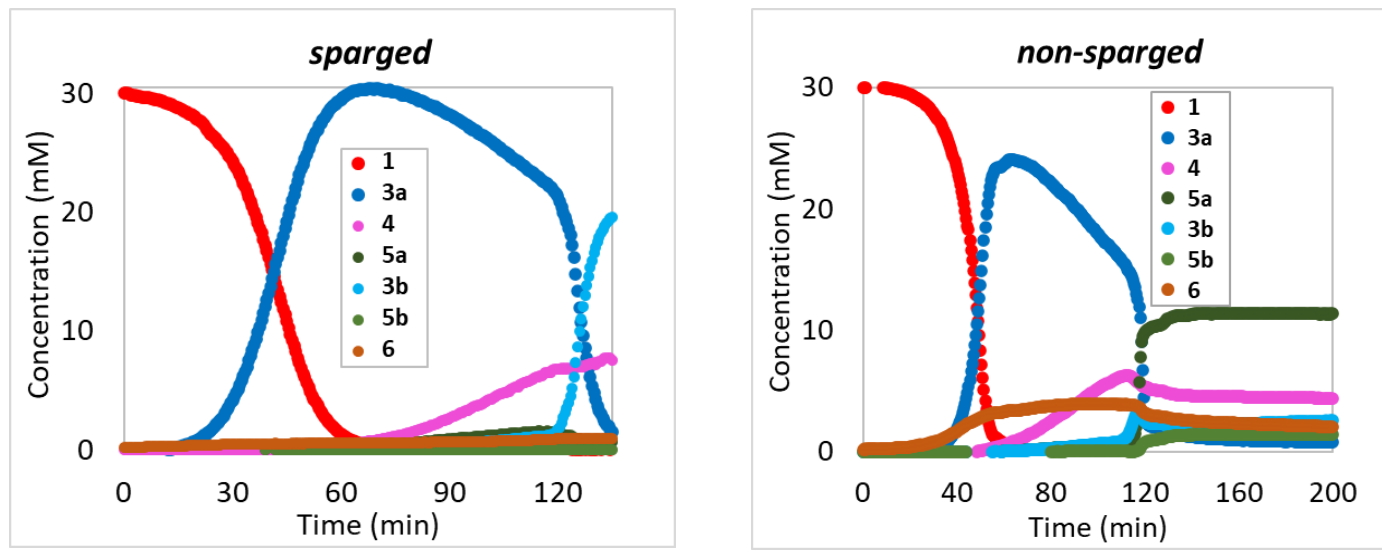

Figure S4. Temporal concentration profiles monitored by ${ }^{1} \mathrm{H}$ NMR spectroscopy of the photobromination reaction under both sparged and non-sparged conditions. $[1]_{0}=30 \mathrm{mM}$, DBDMH (1.05 equiv), $445 \mathrm{~nm}$.

\subsection{Effect of $\mathrm{Br}_{2}$ on the induction period}

The addition of 5 mol\% of molecular bromine $\left(\mathrm{Br}_{2}\right)$ eliminates the induction period.
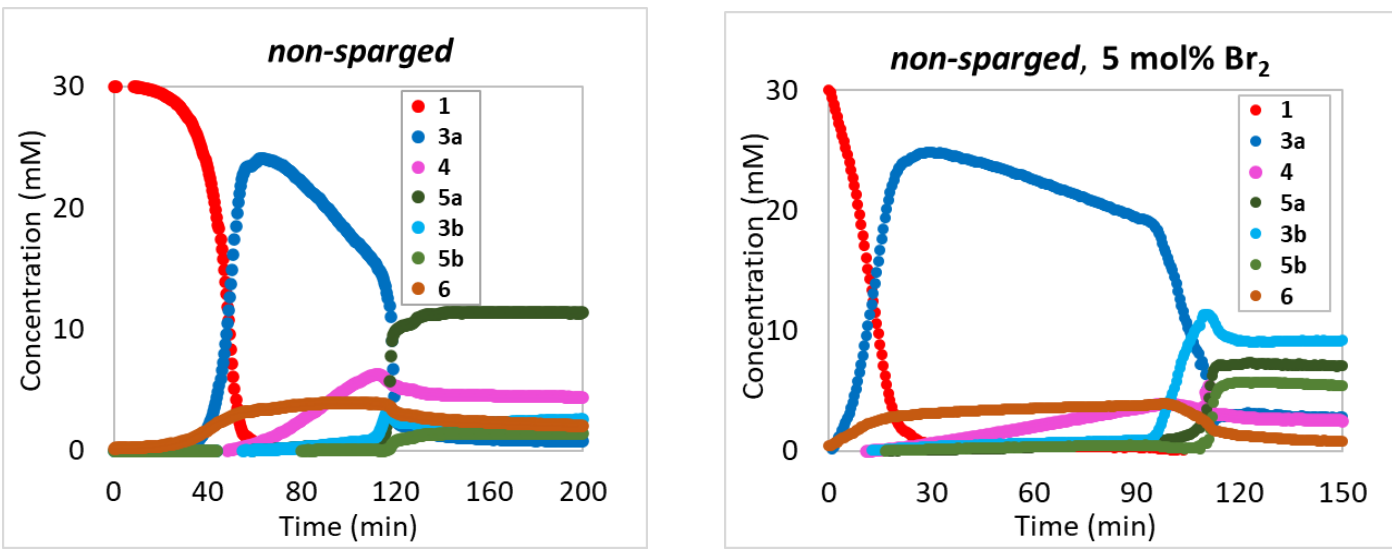

Figure S5. Temporal concentration profiles monitored by ${ }^{1} \mathrm{H}$ NMR spectroscopy of the photobromination reaction in the absence or presence of $5 \mathrm{~mol} \%$ of $\mathrm{Br}_{2}$. [1] $]_{0}=30 \mathrm{mM}, \mathrm{DBDMH}$ (1.05 equiv), $445 \mathrm{~nm}$. 


\subsection{Effect of citric acid on the induction period}

Similar to $\mathrm{Br}_{2}$, the addition of 5 mol\% of citric acid could also eliminate the induction period. Consistently, the reaction mixture with citric acid as an additive showed an increased absorbance at $445 \mathrm{~nm}$.
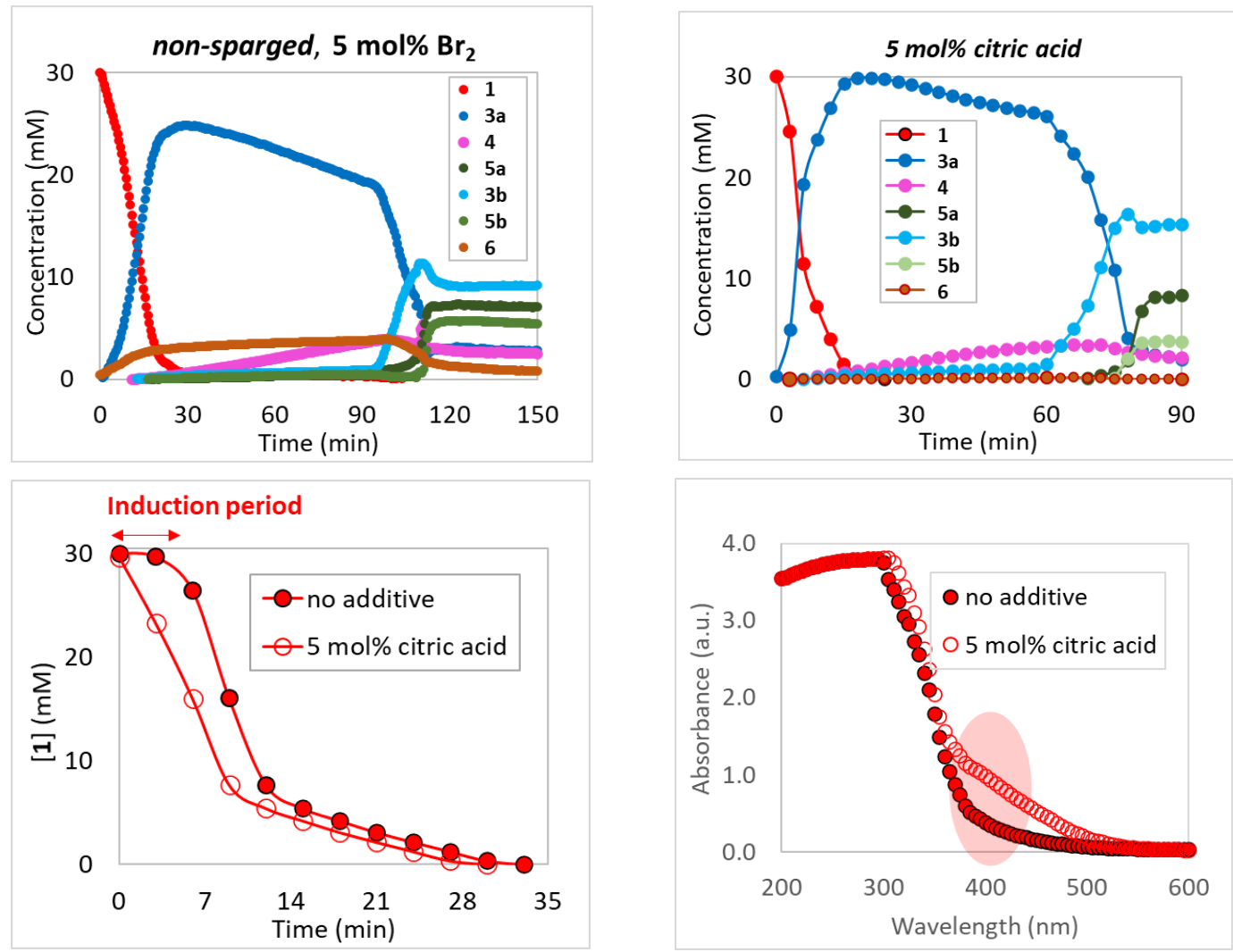

Figure S6. Temporal concentration profiles monitored by ${ }^{1} \mathrm{H}$ NMR spectroscopy of the photobromination reaction in the absence or presence of $5 \mathrm{~mol} \%$ of citric acid. [1 $]_{0}=30 \mathrm{mM}$, DBDMH (1.05 equiv). UV-Vis absorbance spectra of the reaction mixture in the presence or absence of $5 \mathrm{~mol} \%$ of citric acid, increased absorbance at $445 \mathrm{~nm}$ is observed in the presence of citric acid.

\subsection{Effect of the equivalents of DBDMH $2 a$ on the reaction performance}

Independent of the equivalents of DBDMH 2a, the cliff onset always correlates with the full consumption of $\mathbf{2} \mathbf{b}$. Higher equivalents of DBDMH $\mathbf{2} \mathbf{a}$ led to a much faster accumulation of gemdibromide impurity $\mathbf{4}$ and a worse impurity profile. A lower (0.8 equiv) amount of DBDMH led to a cleaner reaction with a delayed cliff compared to 1.05 equiv of DBDMH. Even though the cliff 
onset is delayed at high equivalents of DBDMH (2.1 equiv), almost no product plateau was observed, and it was followed by continuous and substantial decomposition before the cliff.
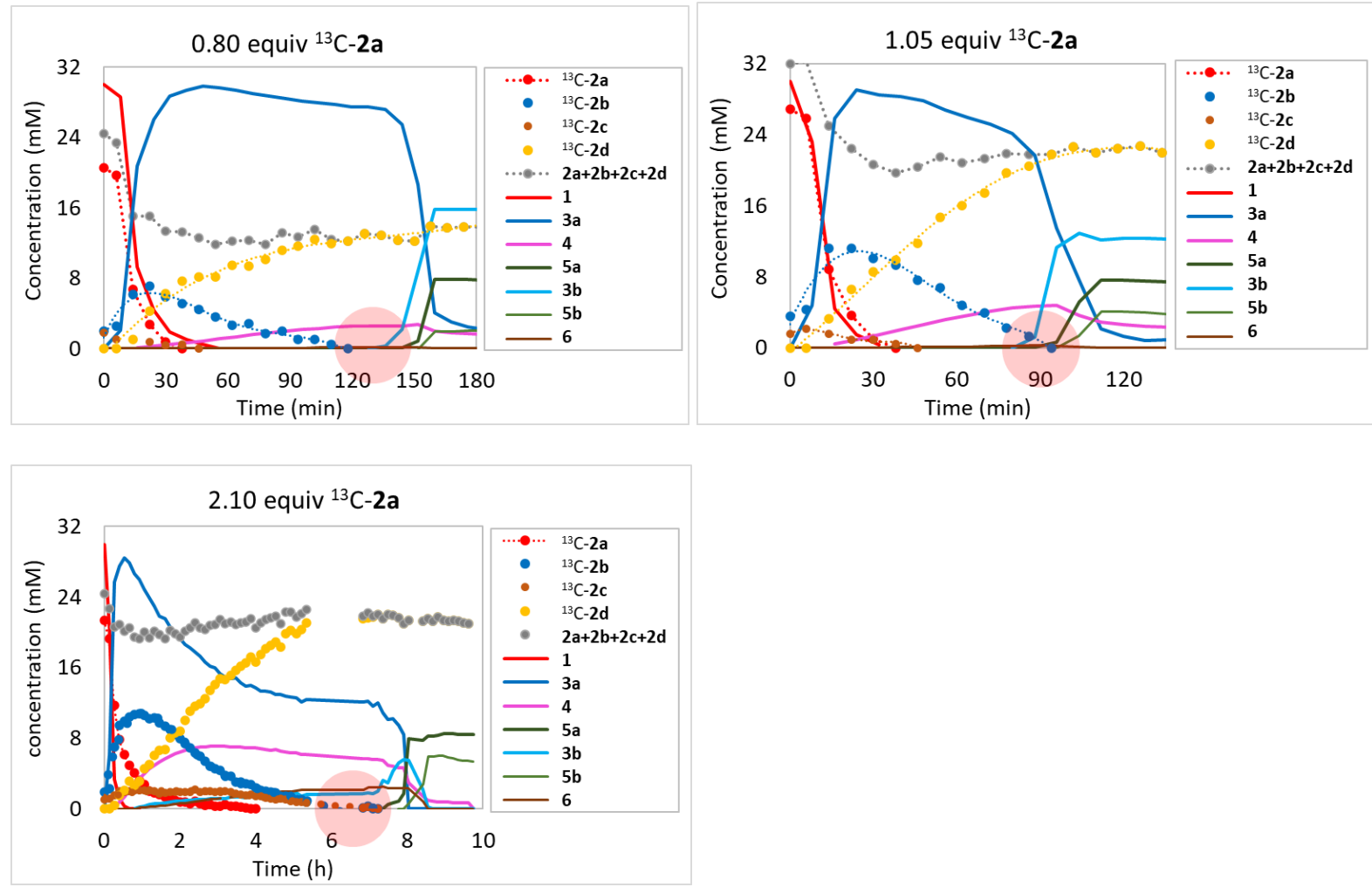

Figure S7. Temporal concentration profiles monitored by ${ }^{1} \mathrm{H}$ NMR spectroscopy of the photobromination reaction using $0.80,1.05$, and 2.10 equiv of DBDMH $\mathbf{2 a}$. [1 $]_{0}=30 \mathrm{mM}, 445$ $\mathrm{nm}$. 


\section{$3 \mathrm{DBDMH}$ and its derivatives}

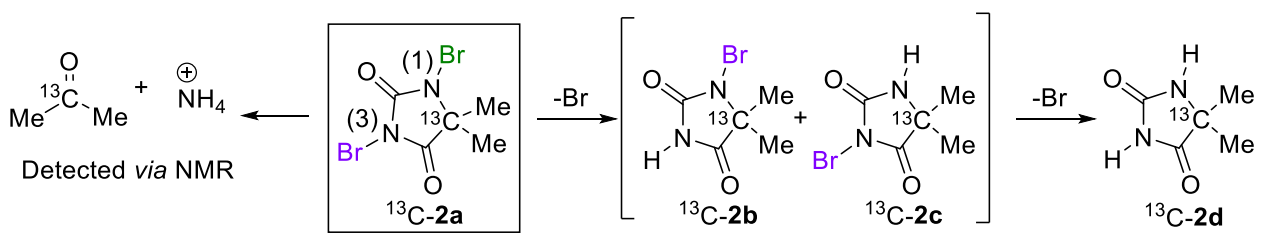

Scheme S2. Decomposition pathways of ${ }^{13} \mathrm{C}-2 \mathbf{a}$ under irradiation at $445 \mathrm{~nm}$.
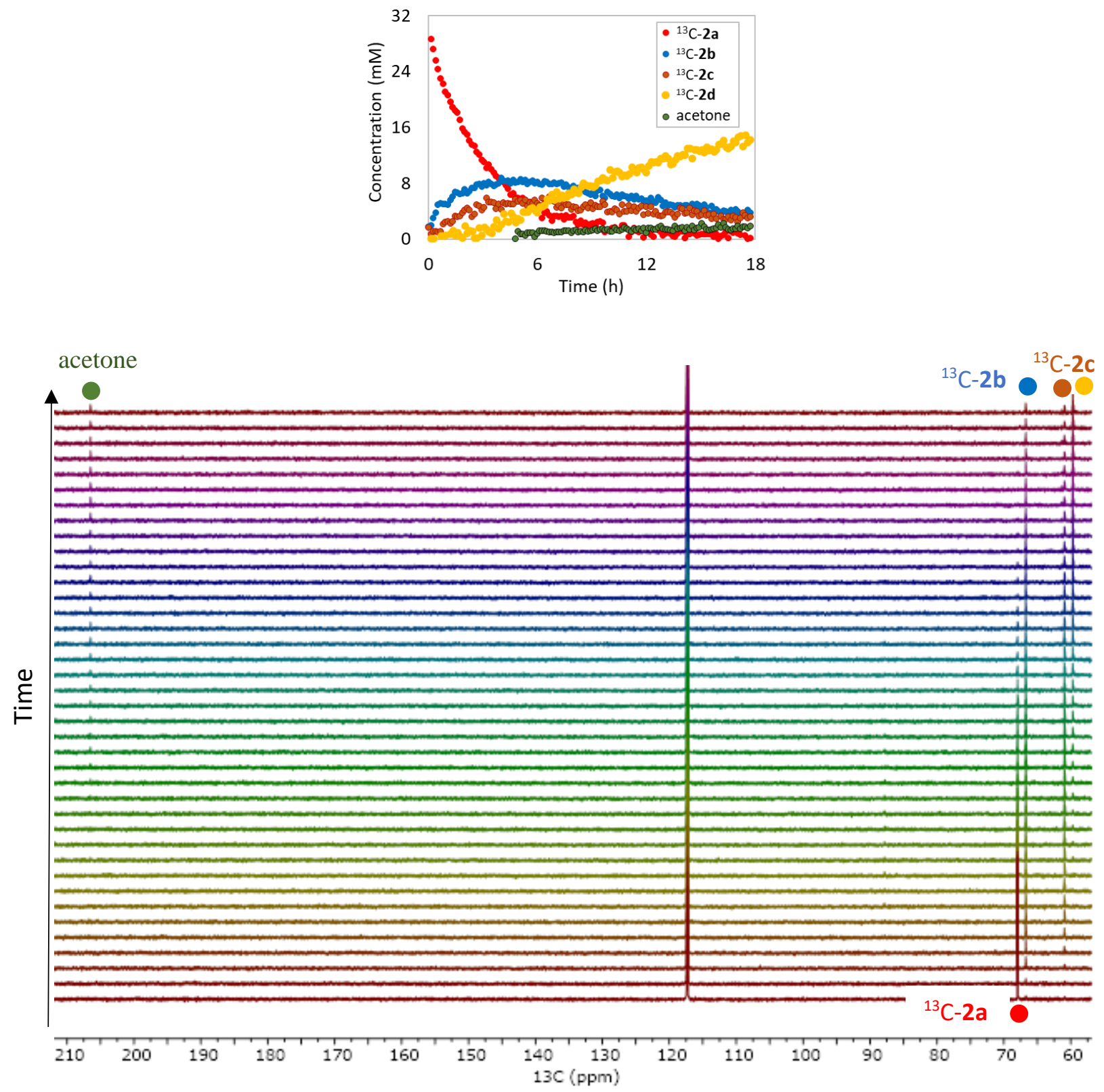


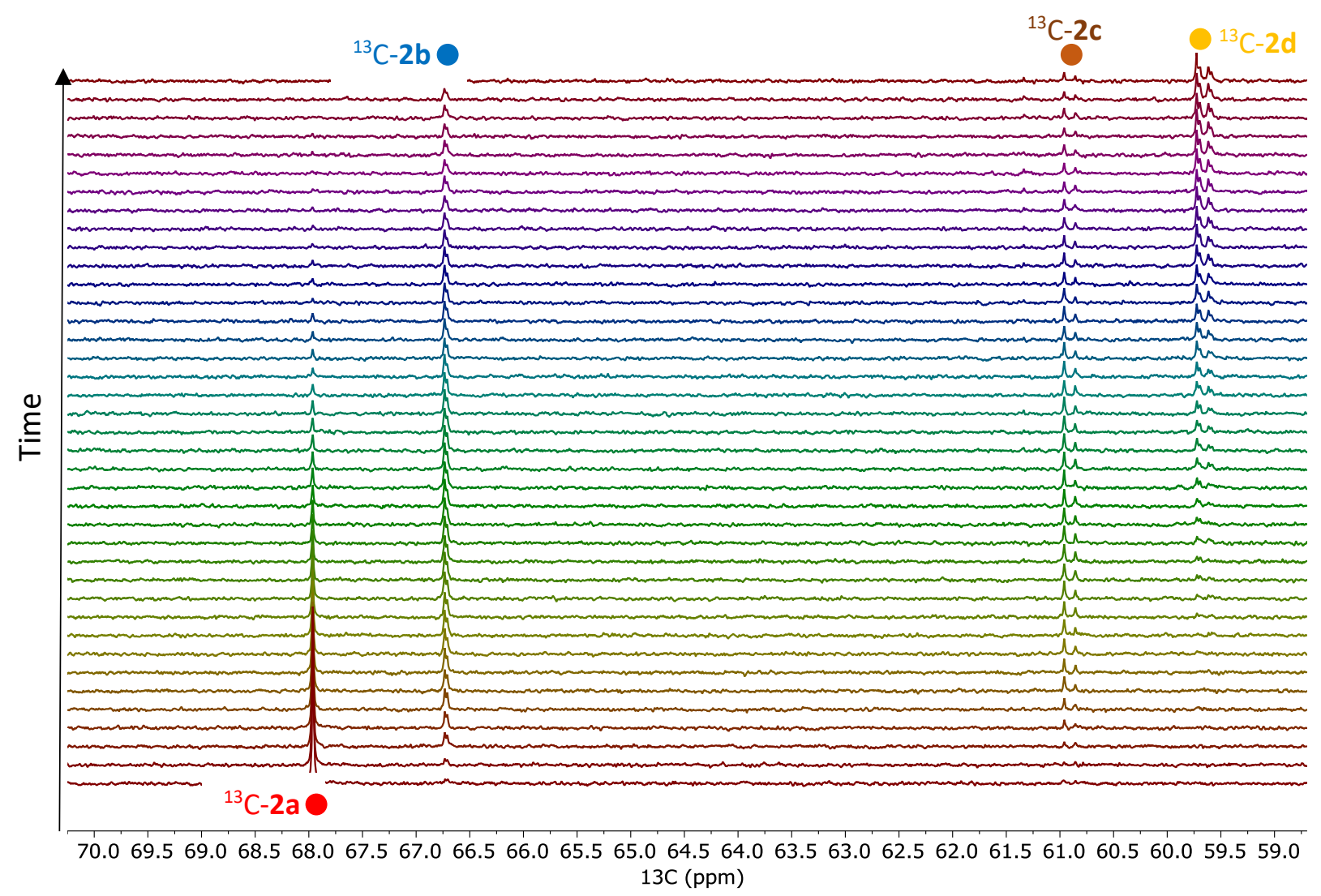

Figure S8. Overlap of ${ }^{13} \mathrm{C}$ NMR spectroscopy over time when subjecting ${ }^{13} \mathrm{C}-2 \mathrm{a}$ under irradiation at $445 \mathrm{~nm}$. [2a $]_{0}=30 \mathrm{mM}$. Top (60-210 ppm). Bottom (59-70 ppm). The time scale of the stacked NMR spectra matches the time scale of the concentration plot.

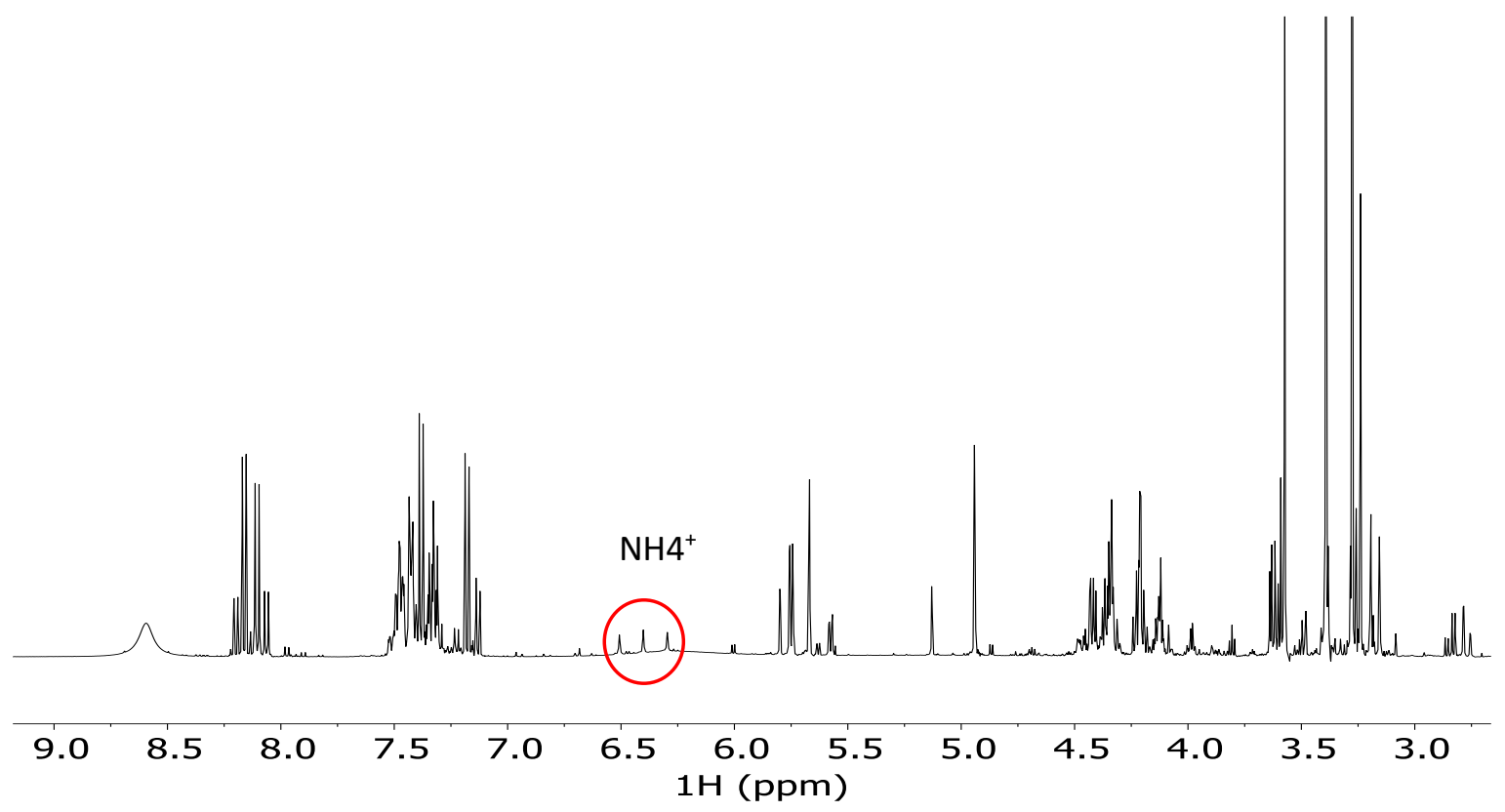

Figure S9. ${ }^{1} \mathrm{H}$ NMR spectroscopy showing the presence of $\mathrm{NH}_{4}{ }^{+}(6.40 \mathrm{ppm}(\mathrm{t}, J=52.8 \mathrm{~Hz}))$ in the reaction medium. 


\section{Role of 4}

Side-product 4 could eliminate $\mathrm{HBr}$ upon degradation, further contributing to the medium acidification and increasing the risk of sudden product decomposition.

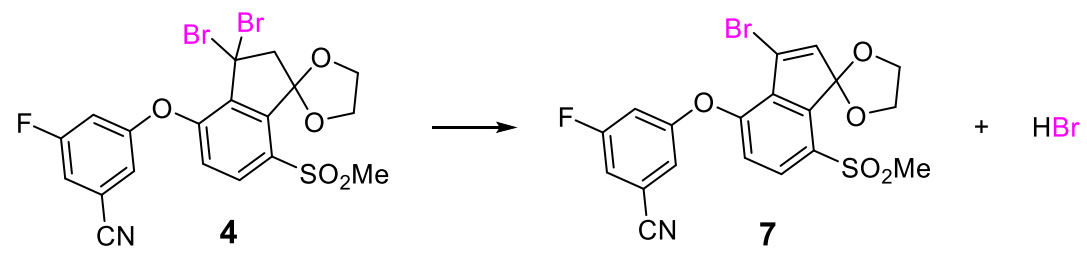

Scheme S3. Degradation pathway of 4.

\subsection{Stability of unquenched streams versus \% of 4}

While streams with higher content of 4 reach a cliff over time if left unquenched, those with < $5 \%$ LCAP of 4 are relatively stable. The higher the amount of $\mathbf{4}$, the sooner the cliff will take place.

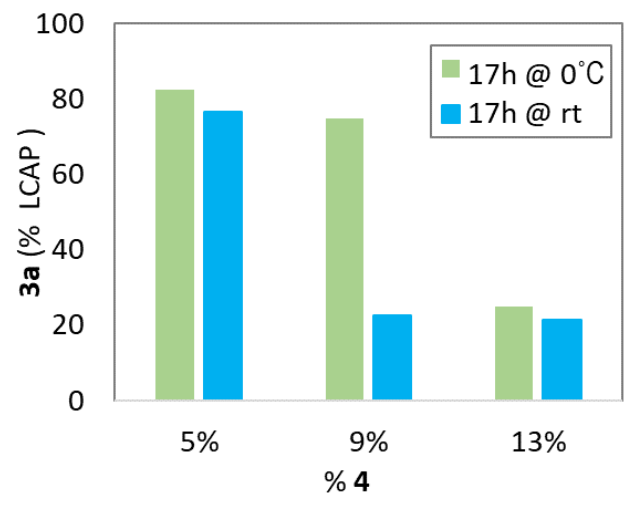

Figure S10. Correlation between stability of the end of the reaction stream and levels of gemdibromide 4 present.

\subsection{Effect of 4 on the cliff}

If the light is turned off right after complete conversion has been achieved, at which point the concentration of the side-product 4 is low: 1) the reaction stream remains in the dark unchanged for $2 \mathrm{~h}$, and 2) extensive heating at $50{ }^{\circ} \mathrm{C}$ over $38 \mathrm{~h}$ was required to cause the cliff. 


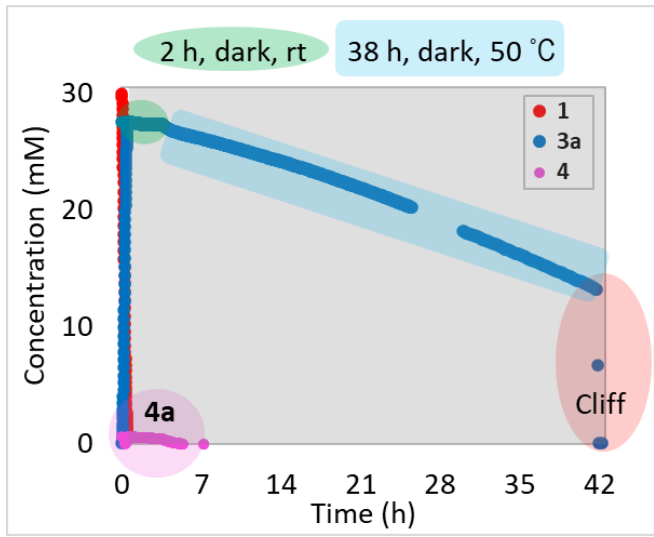

Figure S11. Temporal concentration profiles monitored by ${ }^{1} \mathrm{H}$ NMR spectroscopy of the photobromination reaction under both irradiation and dark conditions. [1 $]_{0}=30 \mathrm{mM}, \mathrm{DBDMH}$ (1.05 equiv), $445 \mathrm{~nm}$. The light was switched off at reaction completion. The remaining sideproducts $(\mathbf{5} \mathbf{a}, \mathbf{3} \mathbf{b}, \mathbf{5} \mathbf{b}$, and $\mathbf{6})$ are omitted in the plot for simplicity.

If the light is turned off when a significant amount of $\mathbf{4}$ has been generated, then a cliff happens in the dark in less than $2 \mathrm{~h}$.

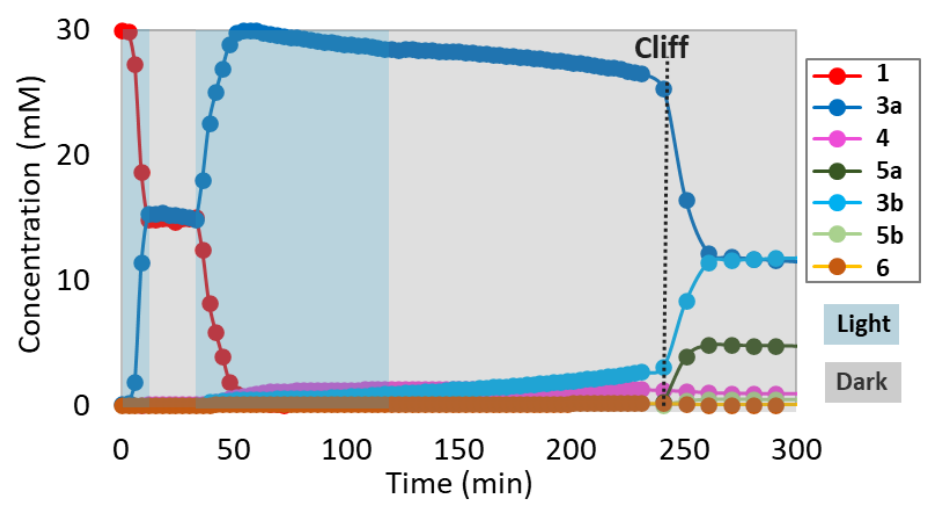

Figure S12. Temporal concentration profiles monitored by ${ }^{1} \mathrm{H}$ NMR spectroscopy of the photobromination reaction under both irradiation and dark conditions. [1 $]_{0}=30 \mathrm{mM}, \mathrm{DBDMH}$ (1.05 equiv). The light was switched off at $12 \mathrm{~min}$ for $24 \mathrm{~min}$, then again after $120 \mathrm{~min}$. 


\section{Citric acid mechanism of action: NMR studies with ${ }^{13} \mathrm{C}$-labeled citric acid}

Citric acid initiates the reaction by activating DBDMH 2a debromination via monobromo intermediates pathway $(\mathbf{2} \mathbf{b}-\mathbf{c})$. Three major products: $\mathrm{CO}_{2}$, tetra- and penta-bromoacetone (TBA and PBA, respectively) are being formed.

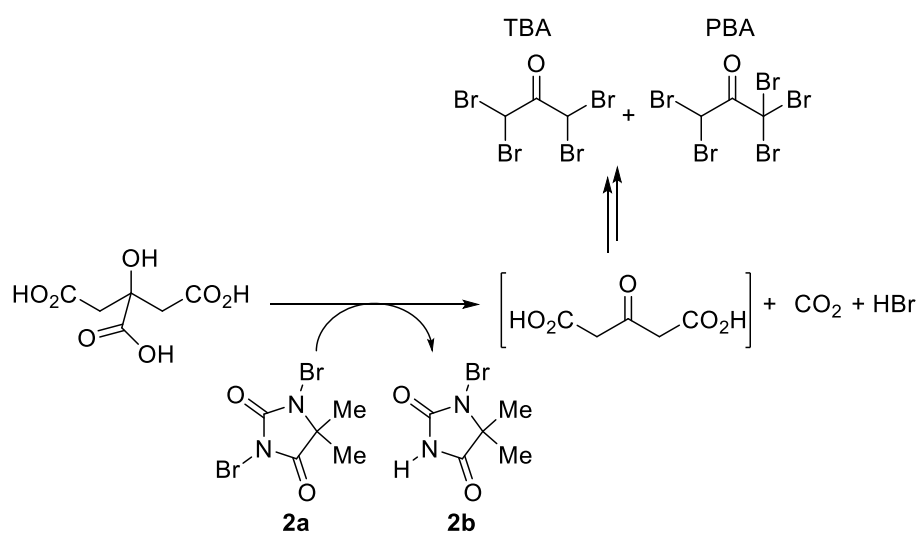

Scheme S4. Degradation pathway of citric acid upon interaction with DBDMH 2a.

In the presence of citric acid, the mass balance of all hydantoin species $(\mathbf{2 a}-\mathbf{d})$ is preserved in the dark but decreases over time under light, consistent with DBDMH decomposition under the light. In typical process conditions (5 mol\% citric acid), most of citric acid is already converted to $\mathrm{CO}_{2}$ and TBA by the time the full reaction mixture is prepared (Fig. S14).
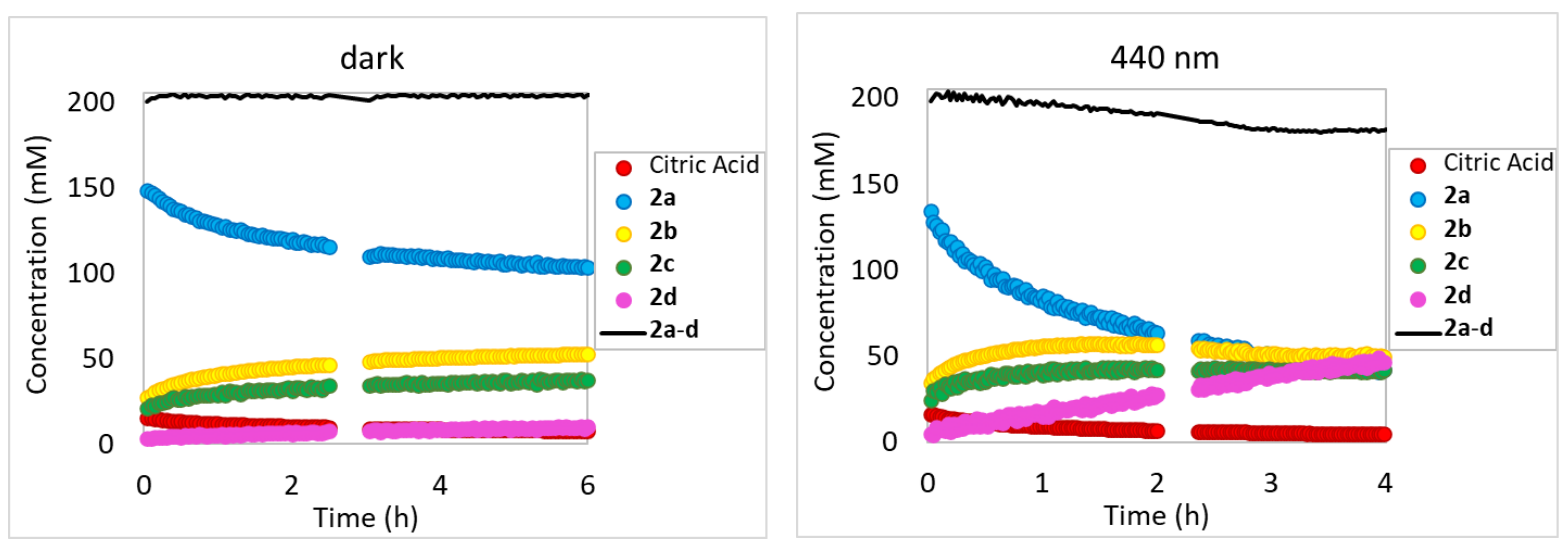

Figure S13. Temporal concentration profiles monitored by ${ }^{1} \mathrm{H}$ NMR spectroscopy of a mixture of DBDMH $2 \mathbf{a}$ and citric acid (1:10) under both light and dark conditions. [2a] = $200 \mathrm{mM}$, citric acid $-{ }^{13} \mathrm{C}_{6}=20 \mathrm{mM}$. 


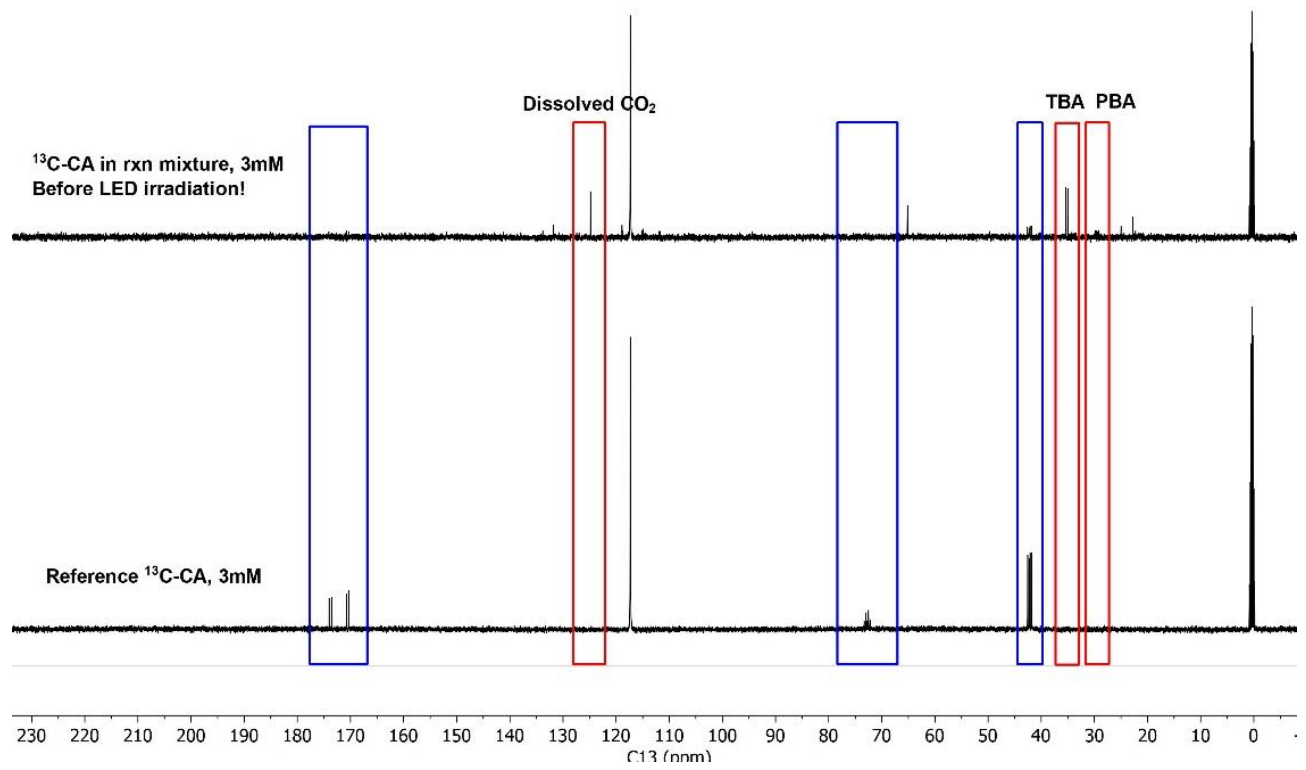

Figure S14. ${ }^{13} \mathrm{C}$ NMR spectroscopy of reaction mixture before LED irradiation (top) and reference of citric acid- ${ }^{13} \mathrm{C}_{6}$ (bottom).

Further experiments have been conducted to rule out TBA and PBA as possible sources of radical bromine.

I. LED-NMR experiments have been performed to monitor the fate of 1,1,3,3-tetrabromoacetone (TBA) and 1,1,1,3,3-pentabromoacetone (PBA) generated from the citric acid (CA). The reaction with $10 \mathrm{~mol} \%$ of ${ }^{13} \mathrm{C}$-labeled CA and using otherwise identical conditions compared to the optimal conditions, was run with ${ }^{13} \mathrm{C}$ NMR monitoring of the products of the ${ }^{13} \mathrm{C}-\mathrm{CA}$. Consistent with the mechanistic model described in the manuscript, CA underwent decomposition in the reaction mixture in the dark, before the LED was turned on. The experiment demonstrated that the levels of major products of ${ }^{13} \mathrm{C}-\mathrm{CA}\left({ }^{13} \mathrm{C}-\mathrm{CO}_{2},{ }^{13} \mathrm{C}-\mathrm{TBA}\right.$ and $\left.{ }^{13} \mathrm{C}-\mathrm{PBA}\right)$ remain unchanged throughout the reaction. The results are depicted in the figure below: 


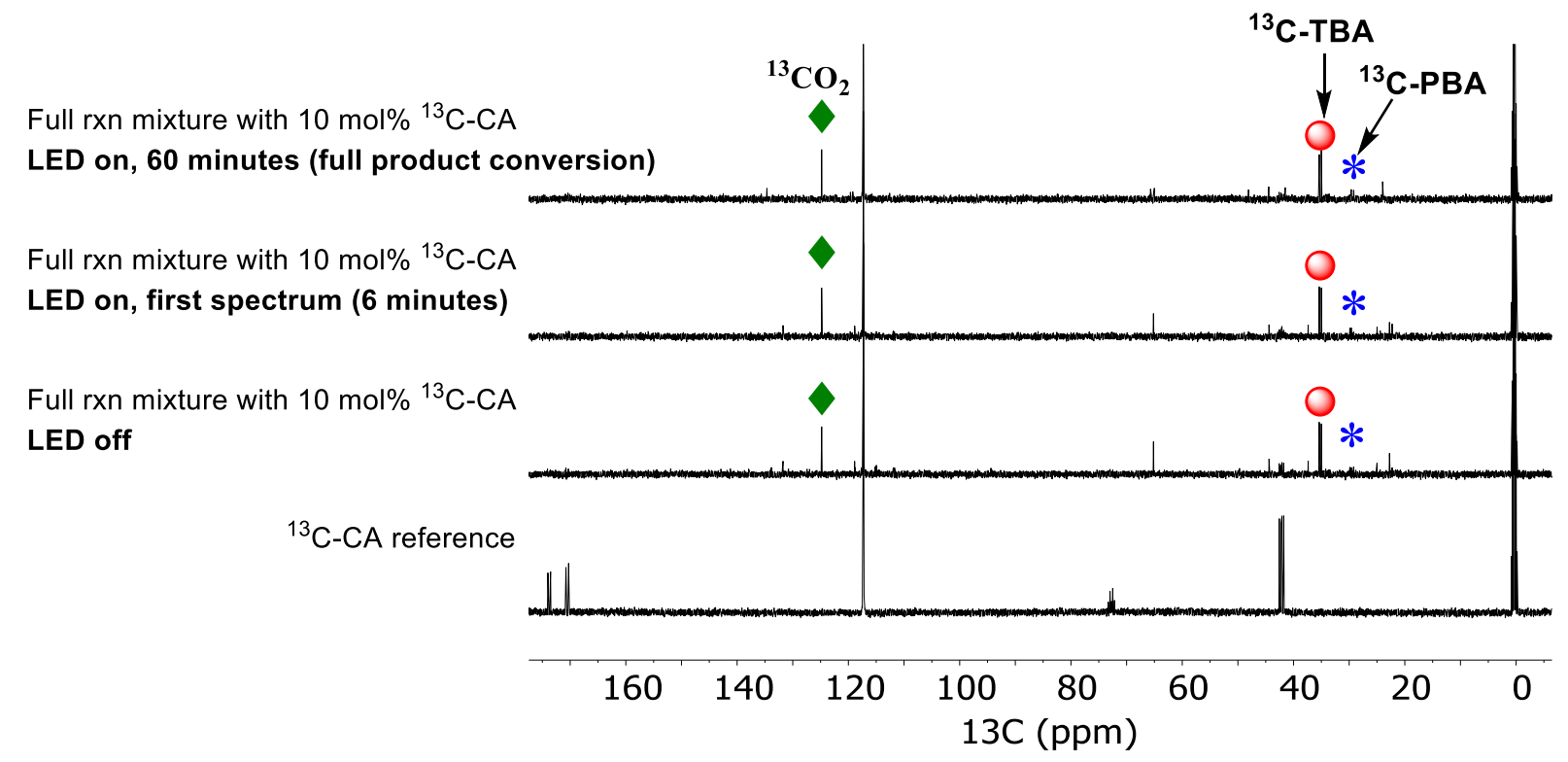

Figure S15. ${ }^{13} \mathrm{C}$ NMR spectroscopy of the reaction mixture with $10 \mathrm{~mol} \%$ of ${ }^{13} \mathrm{C}-\mathrm{CA}$ at 0 (LED off), 6 and 60 minutes. The levels of ${ }^{13} \mathrm{C}$-TBA and ${ }^{13} \mathrm{C}$-PBA remain unchanged throughout the reaction.

II. Additional experiments have been performed to investigate TBA and 1,1,1,3,3,3hexabromoacetone (HBA) as brominating reagents. Attempts at photobrominating indanone 1 using either 1.05 equivalents of TBA or 1.05 equivalents of HBA instead of 1,3-dibromo-5,5dimethylhydantoin, using otherwise identical conditions compared to the optimal conditions, did not afford desired bromo product 3a. NMR spectra of the EOR mixtures for all 3 reactions (using DBDMH, HBA and TBA, respectively) are shown in the figure below: 


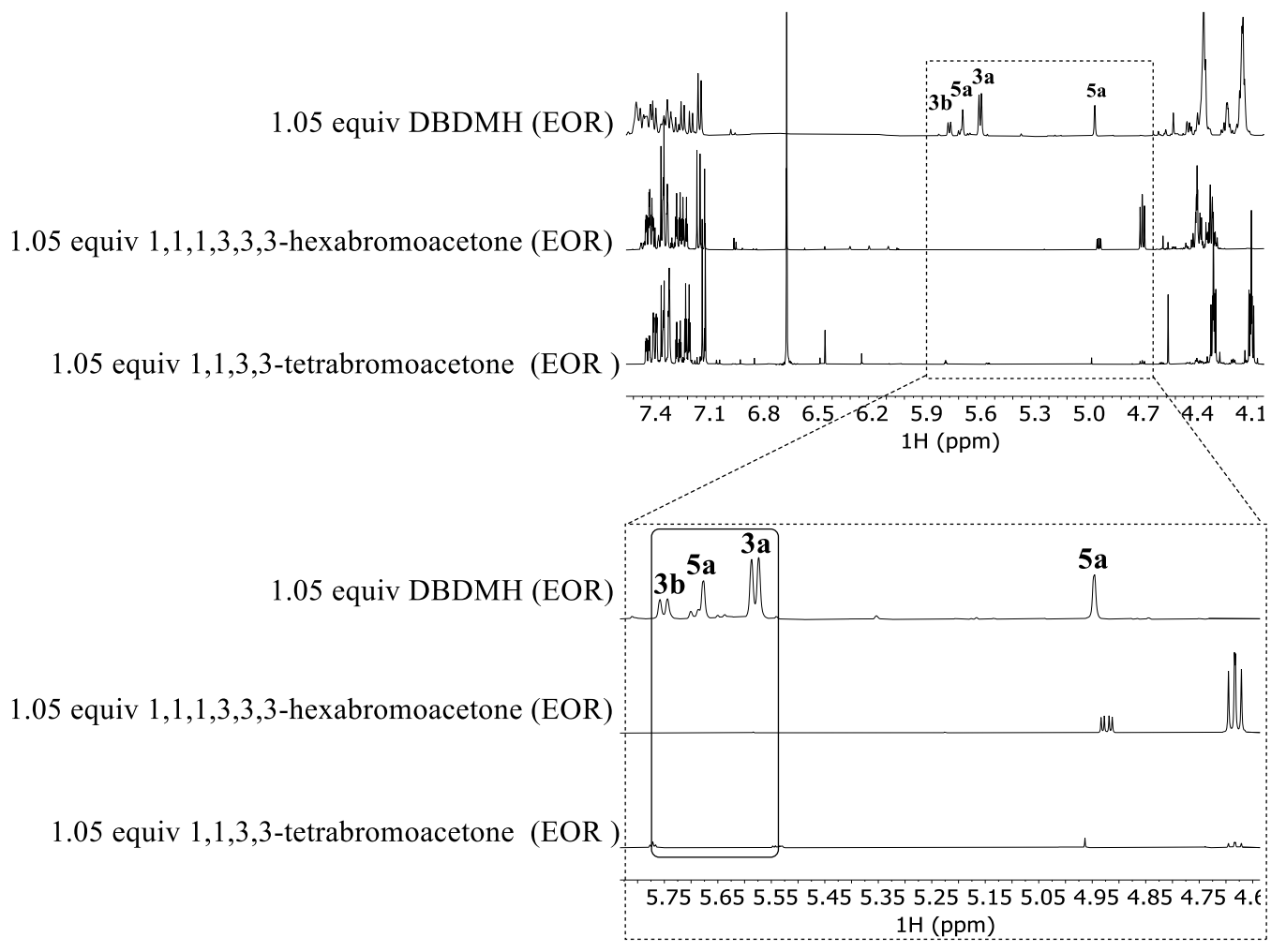

Figure S16. ${ }^{1} \mathrm{H}$ NMR spectroscopy of the reaction mixture at the end of the reaction using DBDMH, 1,1,3,3-tetrabromoacetone (TBA), and 1,1,1,3,3,3-hexabromoacetone (HBA) as the brominating agents. Both TBA and HBA did not provide the desired product 3a or other dibromo side-products such as 5a. Reaction conditions: [1 $]_{0}=128.5 \mathrm{mM}, \mathrm{DBDMH}$ (1.05 equiv). The reaction solution was subject to irradiation in an M1 photoreactor ${ }^{1}$ with $450 \mathrm{~nm}$ LED, 20\% intensity, stir rate $=350 \mathrm{rpm}$ and cooling fan at $5200 \mathrm{rpm}$.

${ }^{1}$ Le, C.; Wismer, M. K.; Shi, Z. C.; Zhang, R.; Conway, D. V.; Li, G.; Vachal, P.; Davies, I. W.; MacMillan, D. W. C. A General Small-Scale Reactor to Enable Standardization and Acceleration of Photocatalytic Reactions. ACS Cent. Sci. 2017, 3, 6, 647-653. 


\section{UV-visible absorption spectra}

While both reactants 1 and 2 a nearly absorb at the operating wavelength of $445 \mathrm{~nm}, \mathrm{Br}_{2}$ has a strong absorption at $445 \mathrm{~nm}$.
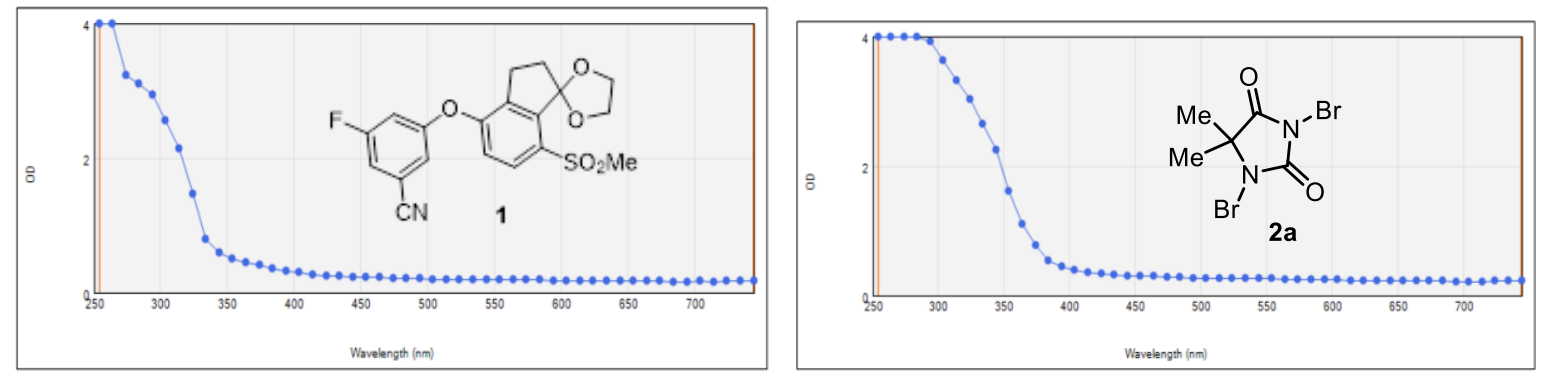

\section{$450 \mathrm{~nm}$}
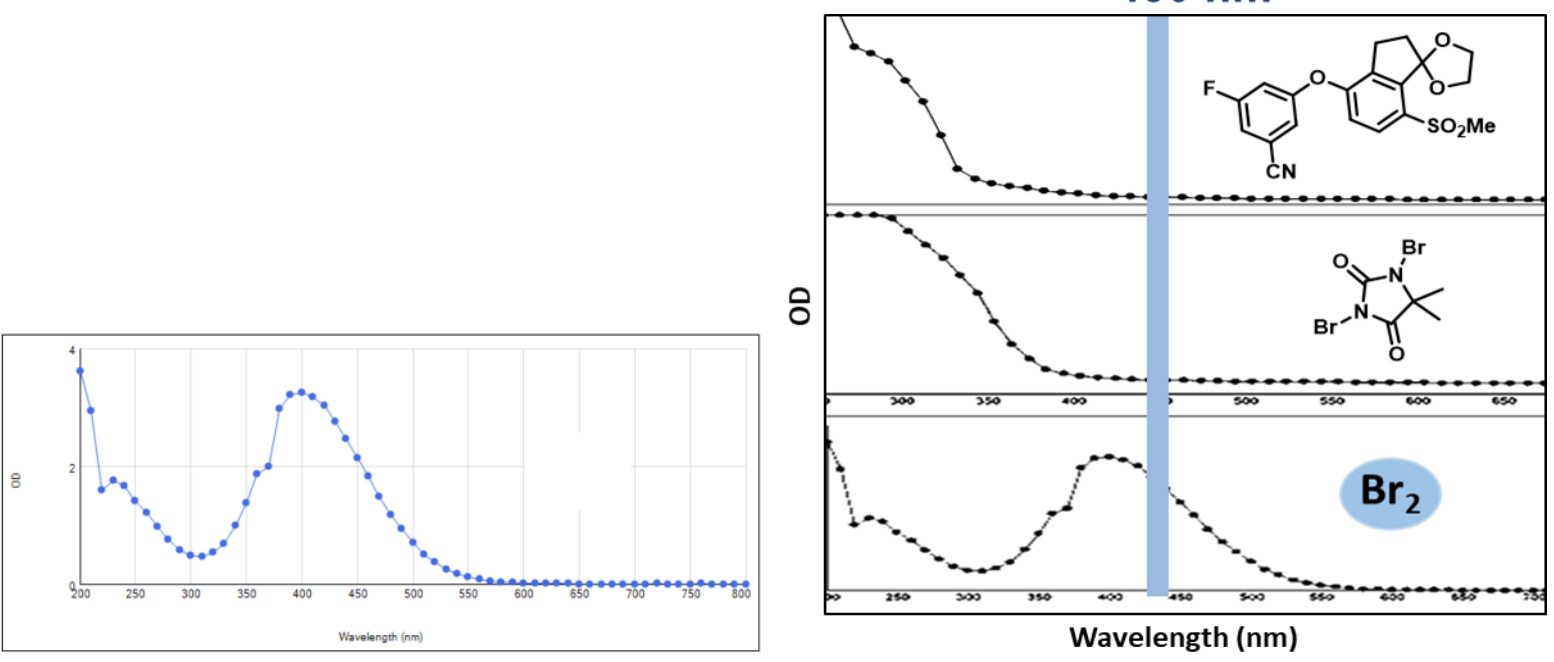

Figure S17. UV-Vis absorbance spectra of starting material 1, DBDMH 2a, and $\mathrm{Br}_{2}$.

UV-visible spectra of the photobromination reaction solution and standard solutions were collected as follows. Four solutions were prepared: 1) a reaction solution mixture of $0.5 \mathrm{~g}$ starting material 1, $0.367 \mathrm{~g}$ of 1,3-dibromo-5,5-dimethylhydantoin (DBDMH) in $10 \mathrm{~mL}$ of acetonitrile; 2) $0.01 \mathrm{M}$ bromine $\left(\mathrm{Br}_{2}\right)$ dissolved in acetonitrile, 3) 0.14 M DBDMH in acetonitrile, and 4) $0.10 \mathrm{M} 1$ in acetonitrile. UV-visible spectra were measured in a Molecular Devices SpectraMax ${ }^{\circledR}$ PLUS 384 UV-vis spectrophotometer equipped with a $2 \mathrm{~mm}$ pathlength quartz cell. All measured spectra used acetonitrile as a reference. The reaction solution was subject to irradiation in an M1 photoreactor $^{1}$ equipped with a $5 \mathrm{~W}$ LED light source at $450 \mathrm{~nm}$. The reaction solution agitated at 
$5200 \mathrm{rpm}$ and irradiated at $20 \%$ power $(1 \mathrm{~W})$ for $6 \mathrm{~min}$. The reaction solution before reaction and after 6 min of irradiation had UV-visible spectra measured. The difference between 6 min irradiation at the initial reaction mixture was compared to the spectra of solutions $2-4$ to highlight bromine formation during the reaction.
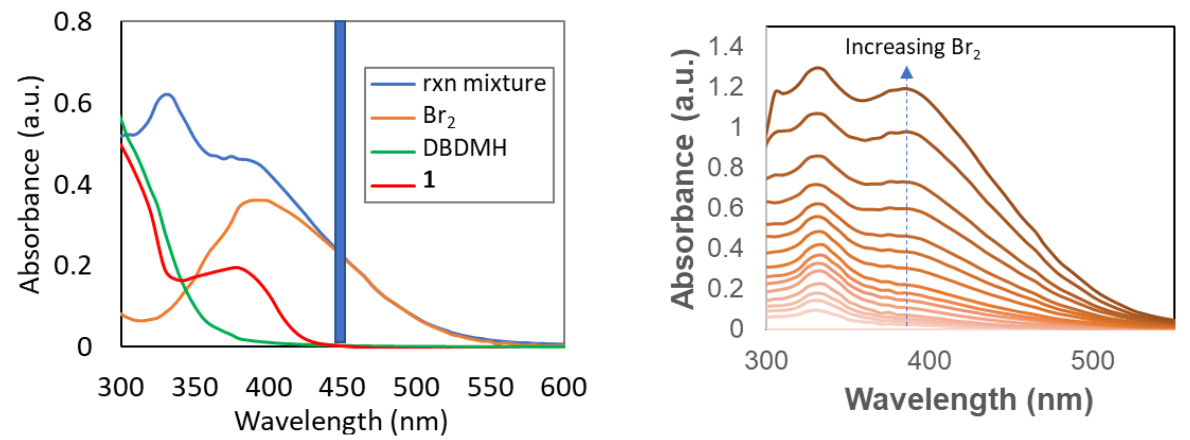

Figure S18. Absorbance spectra $(300-600 \mathrm{~nm})$ of the reaction mixture, starting material 1, $\mathrm{DBDMH}$, and $\mathrm{Br}_{2}$ (Left). Absorbance spectra of the reaction mixture over time indicating the formation and increase of the $\mathrm{Br}_{2}$ (right). 


\section{$7 \quad$ NMR Spectra}
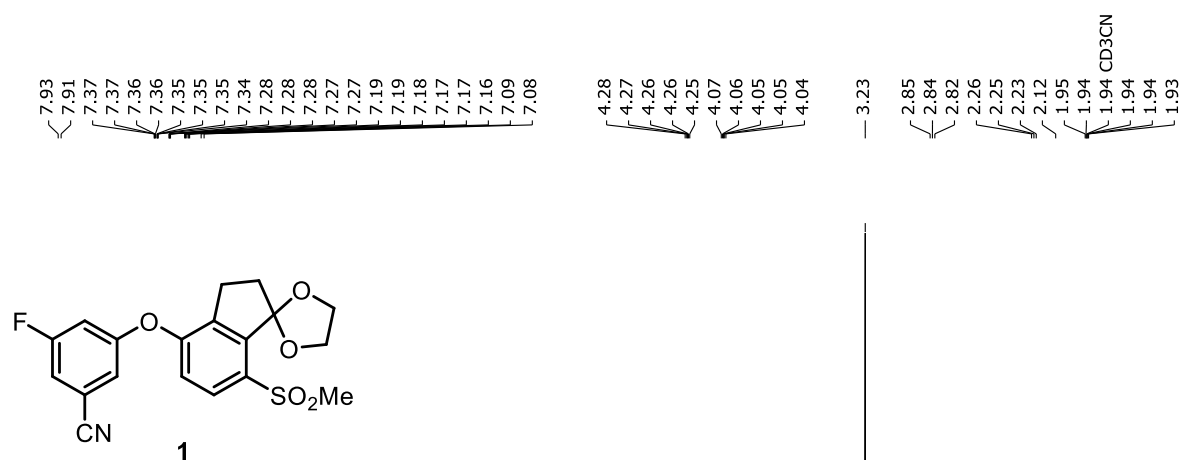

${ }^{1} \mathrm{H}$ NMR $\left(500 \mathrm{MHz}, \mathrm{CD}_{3} \mathrm{CN}\right)$
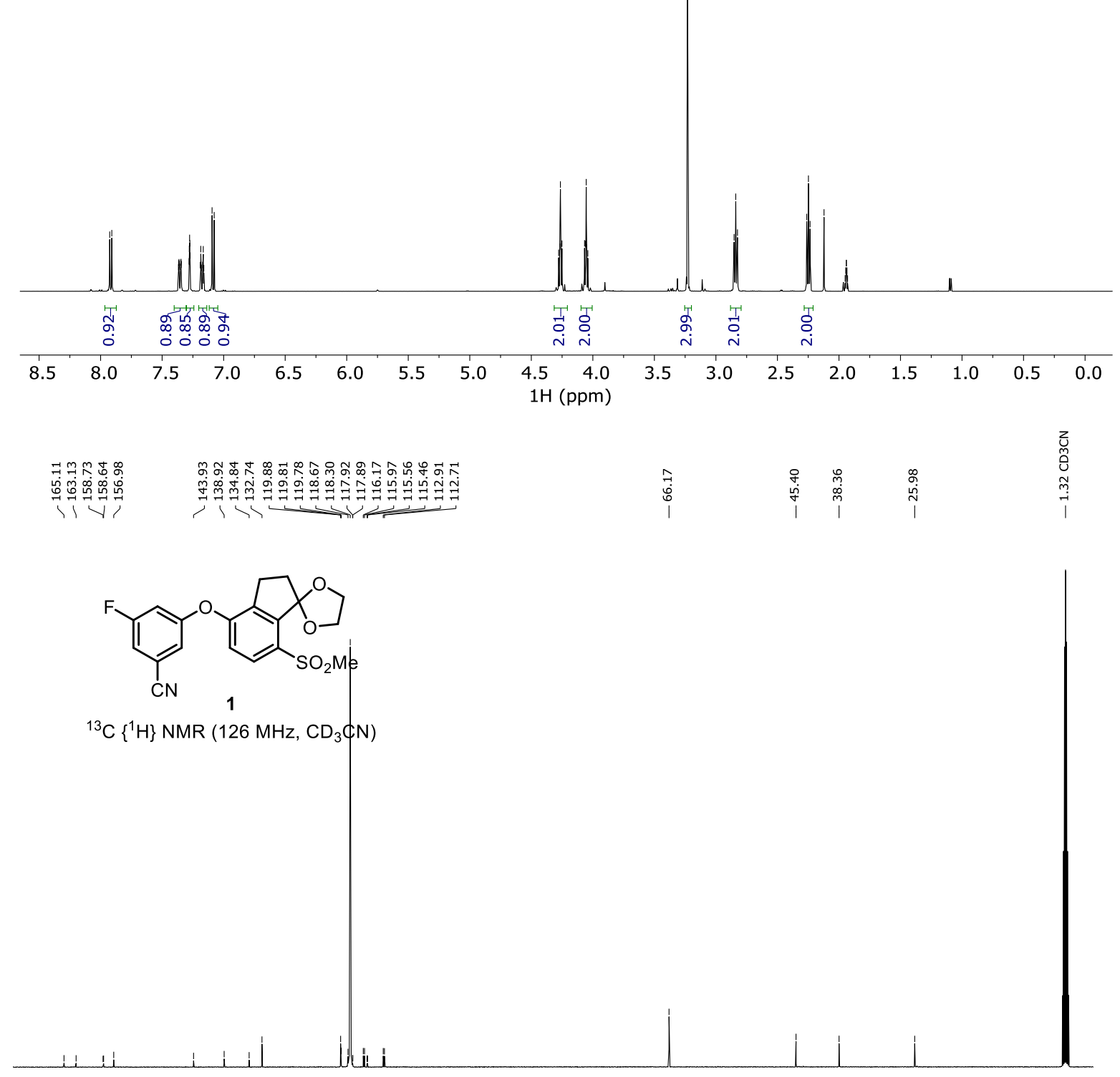

170

160

150

130 

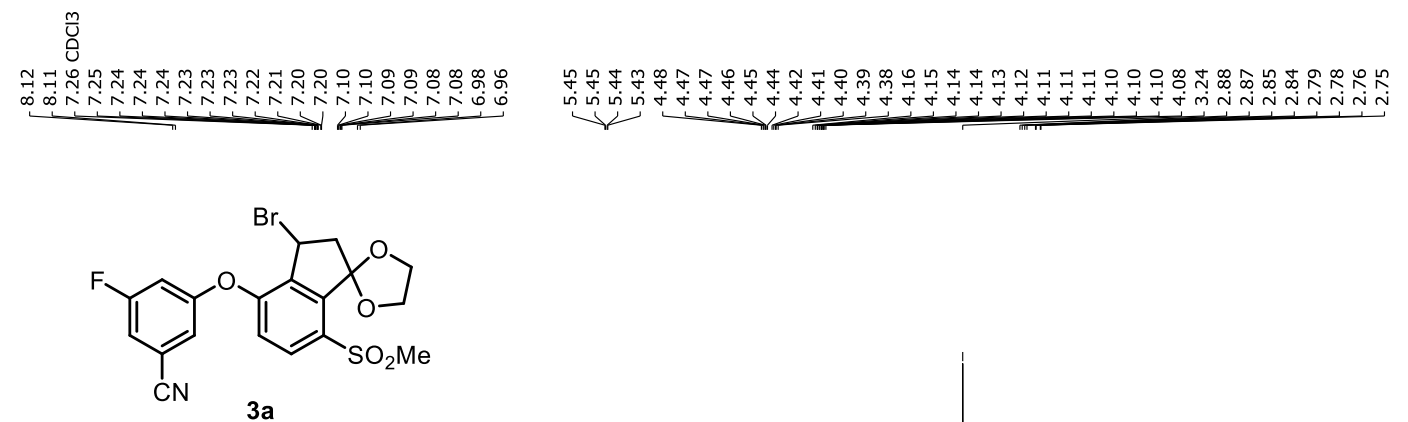

${ }^{1} \mathrm{H}$ NMR $\left(500 \mathrm{MHz}, \mathrm{CDCl}_{3}\right)$

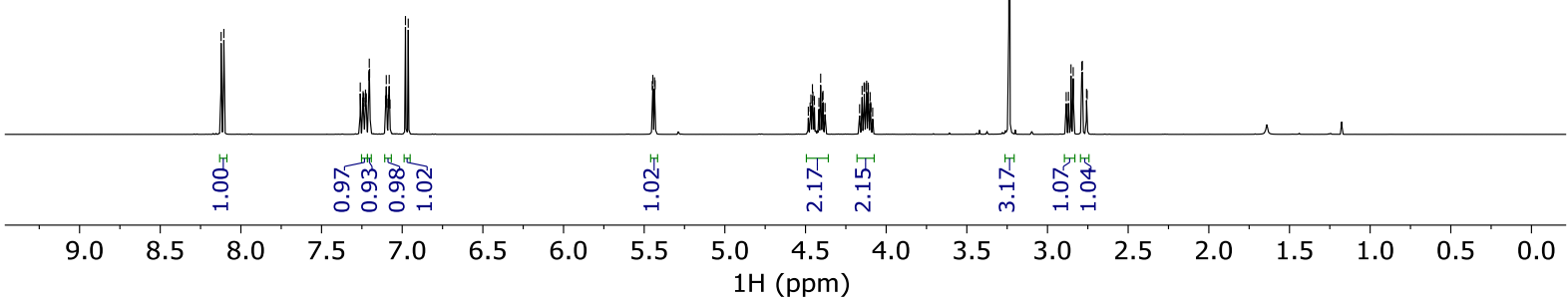

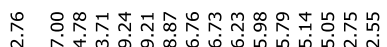

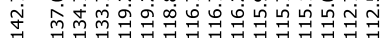

11 प

采
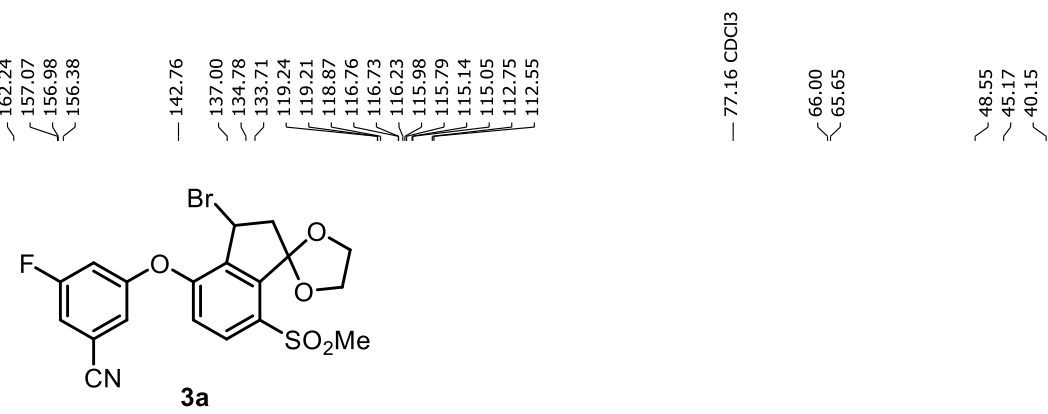

${ }^{13} \mathrm{C}\left\{{ }^{1} \mathrm{H}\right\}$ NMR $\left(126 \mathrm{MHz}, \mathrm{CDCl}_{3}\right)$

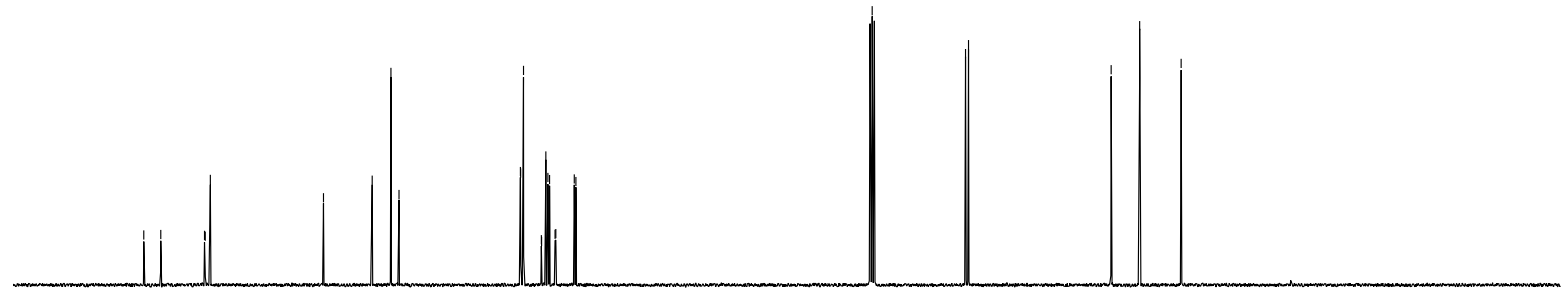

$\begin{array}{llllll}170 & 160 & 150 & 140 & 130 & 120\end{array}$

9080

$13 \mathrm{C}(\mathrm{ppm})$ 


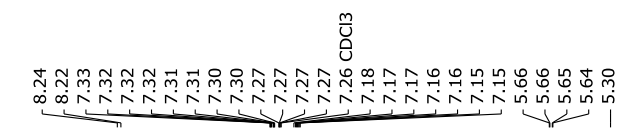

\section{กู่}

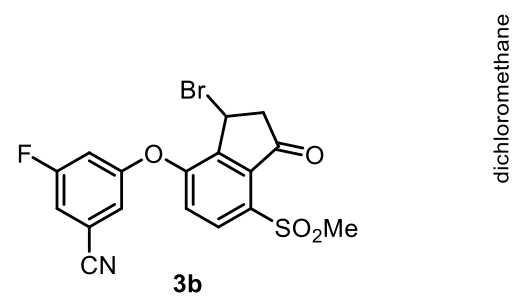

${ }^{1} \mathrm{H}$ NMR $\left(500 \mathrm{MHz}, \mathrm{CDCl}_{3}\right)$
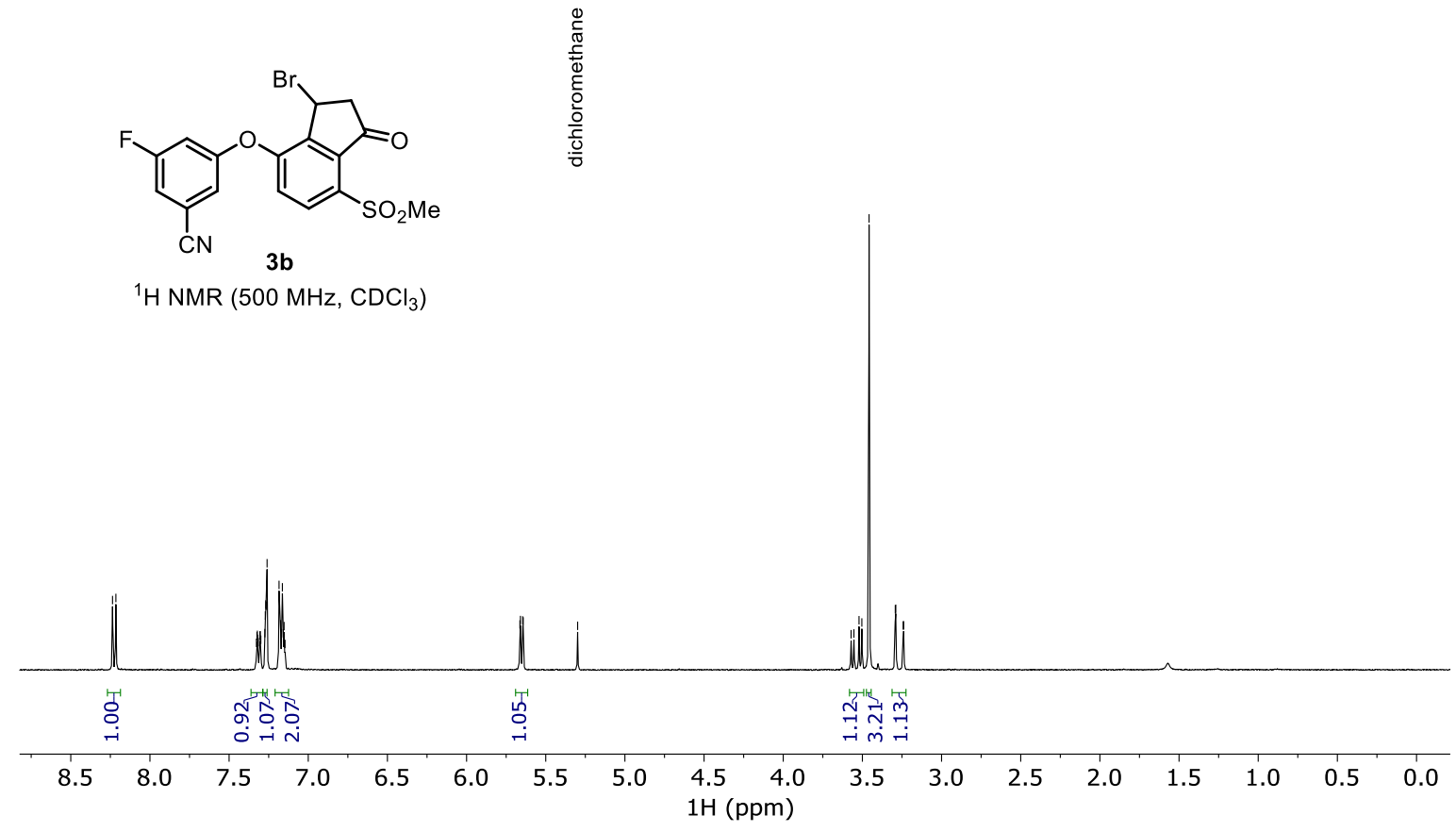

$$
\underset{\substack{1 \\ \stackrel{\infty}{*} \\ \stackrel{1}{1}}}{\stackrel{1}{1}}
$$
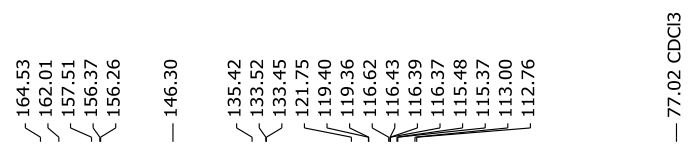

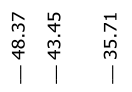

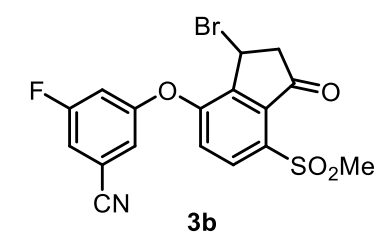

${ }^{13} \mathrm{C}\left\{{ }^{1} \mathrm{H}\right\}$ NMR (126 MHz, $\left.\mathrm{CDCl}_{3}\right)$

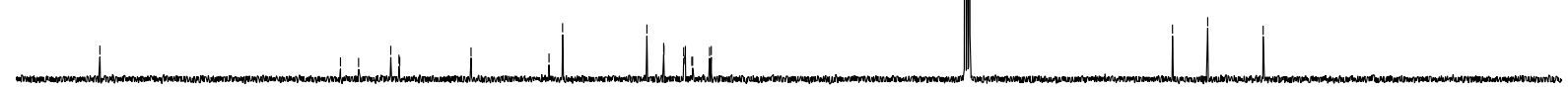

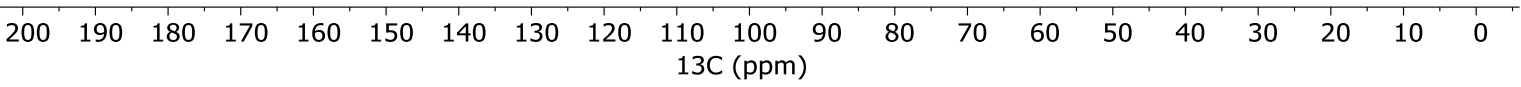




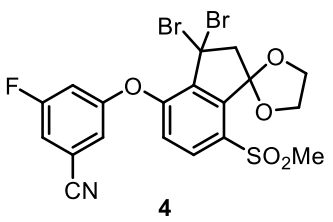

${ }^{1} \mathrm{H} \mathrm{NMR}\left(500 \mathrm{MHz}, \mathrm{CD}_{2} \mathrm{Cl}_{2}\right)$

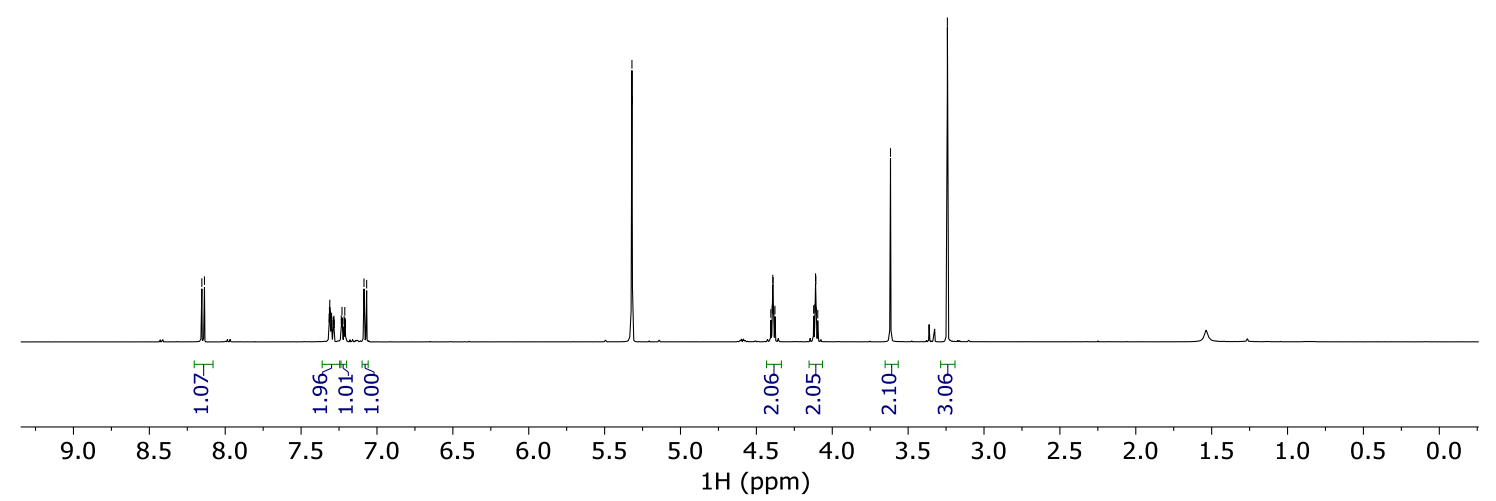

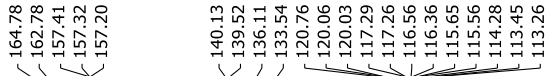

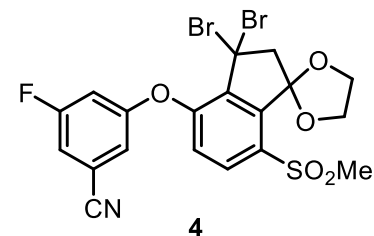

${ }^{13} \mathrm{C}\left\{{ }^{1} \mathrm{H}\right\}$ NMR $\left(126 \mathrm{MHz}, \mathrm{CD}_{2} \mathrm{Cl}_{2}\right)$

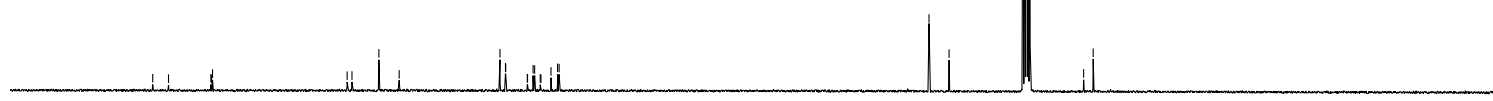



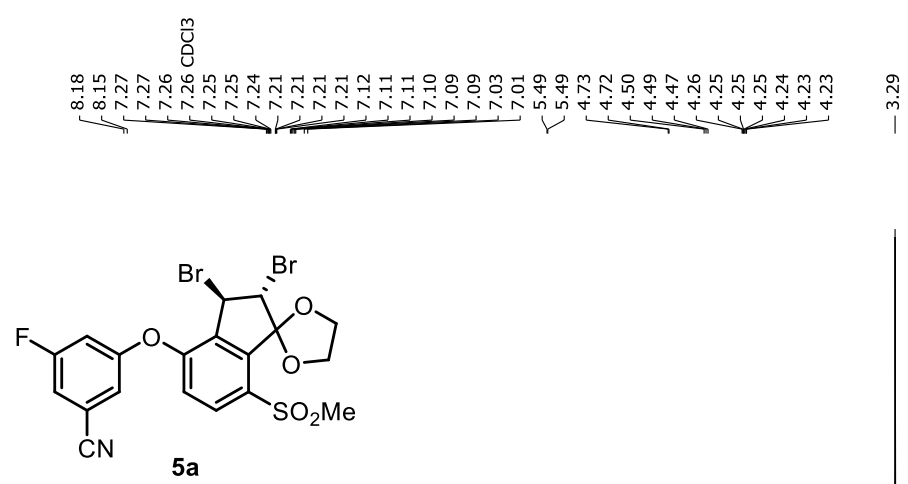

${ }^{1} \mathrm{H}$ NMR $\left(500 \mathrm{MHz}, \mathrm{CDCl}_{3}\right)$

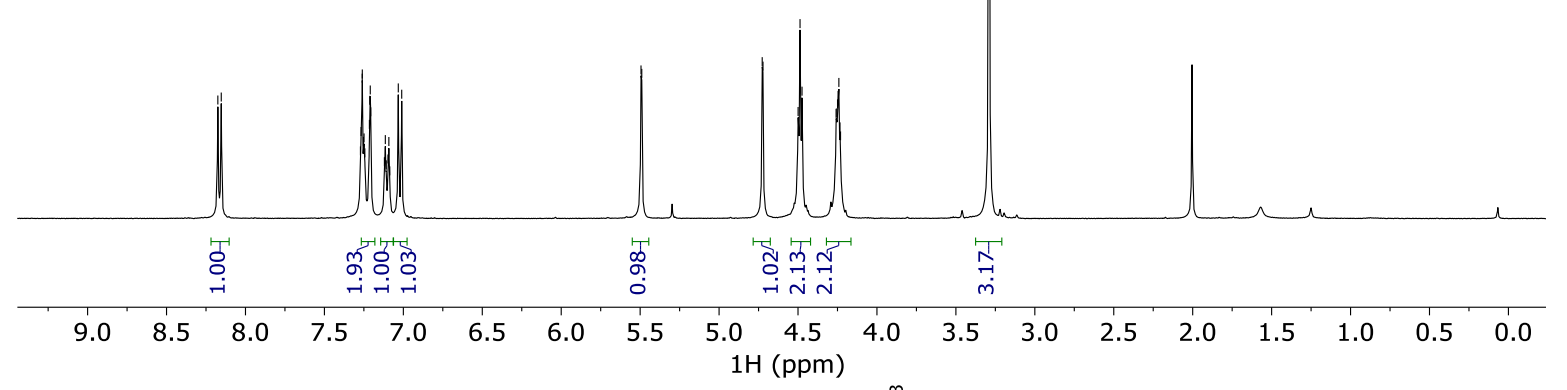

ஸ̊ำ

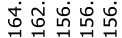

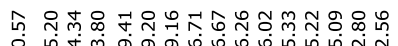

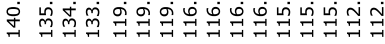

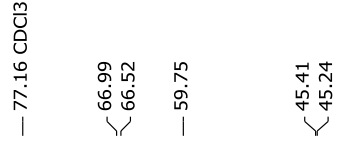

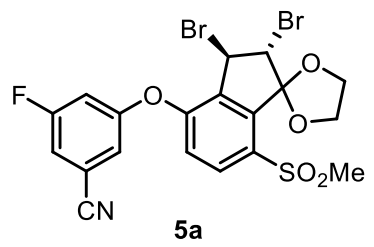

${ }^{13} \mathrm{C}\left\{{ }^{1} \mathrm{H}\right\}$ NMR $\left(126 \mathrm{MHz}, \mathrm{CDCl}_{3}\right)$

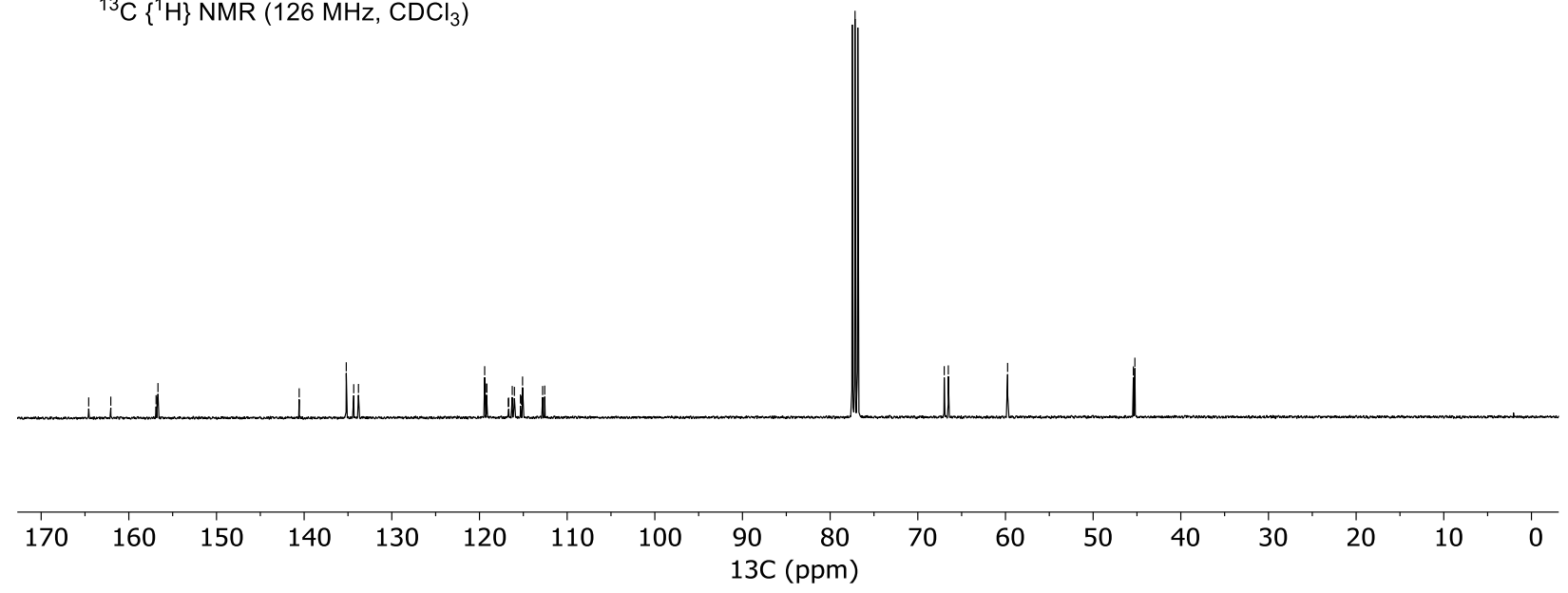



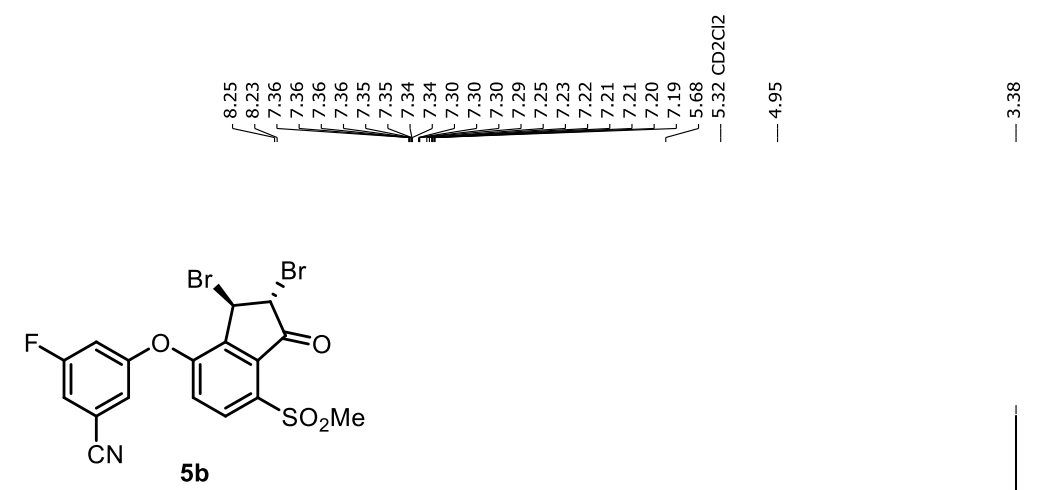

${ }^{1} \mathrm{H}$ NMR $\left(500 \mathrm{MHz}, \mathrm{CD}_{2} \mathrm{Cl}_{2}\right)$
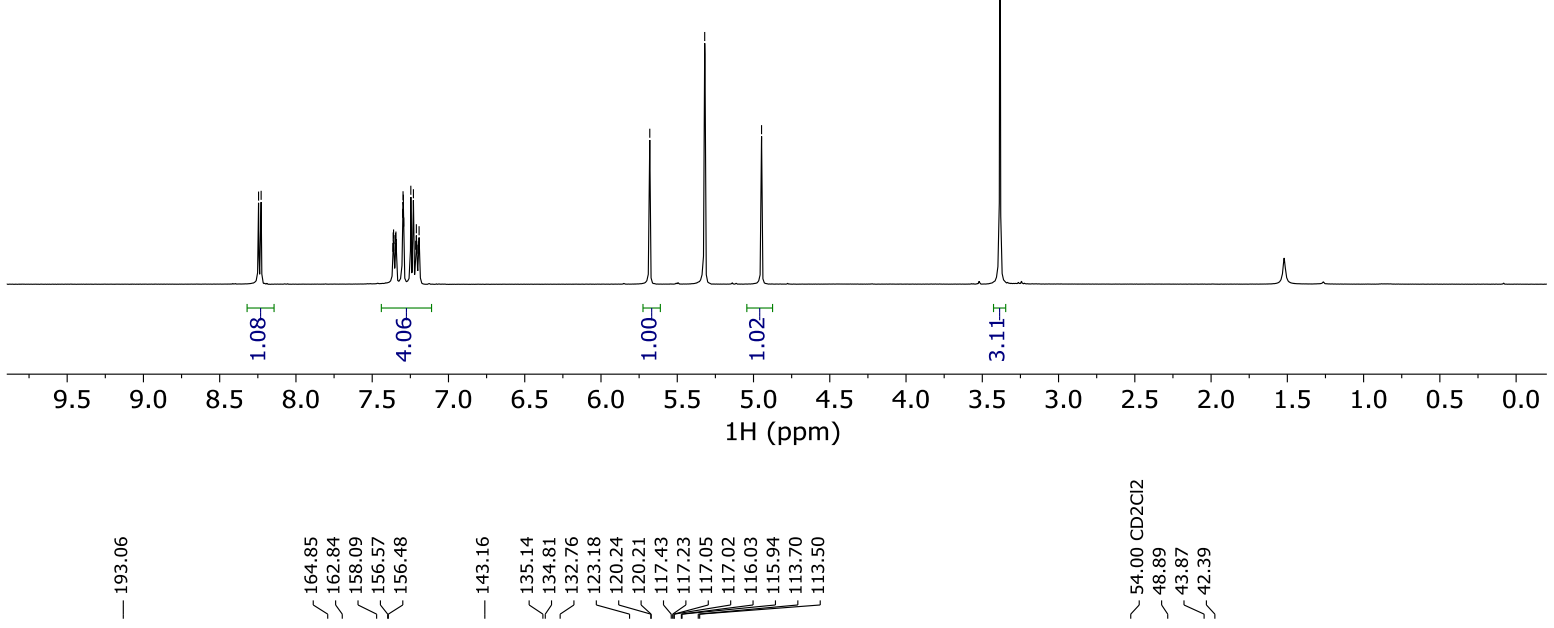

บิ

8 वे

फे y

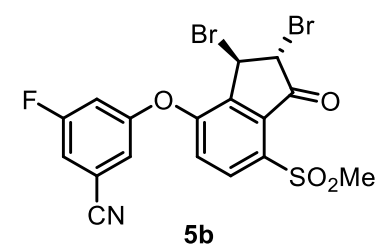

${ }^{13} \mathrm{C}\left\{{ }^{1} \mathrm{H}\right\} \operatorname{NMR}\left(126 \mathrm{MHz}, \mathrm{CD}_{2} \mathrm{Cl}_{2}\right)$

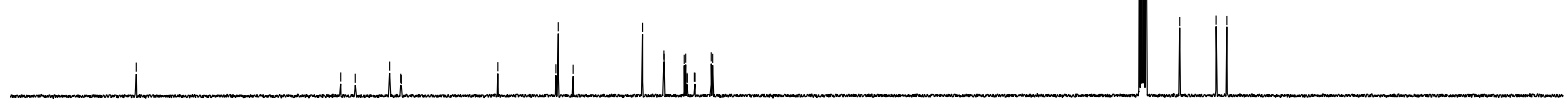

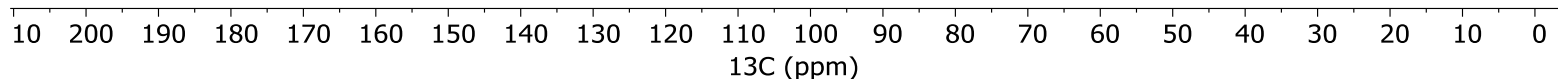



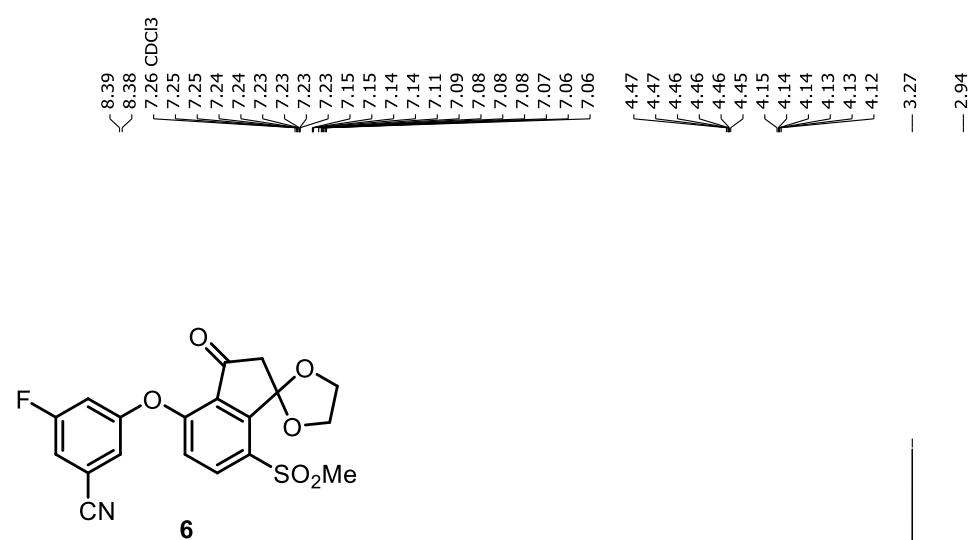

${ }^{1} \mathrm{H}$ NMR $\left(500 \mathrm{MHz}, \mathrm{CDCl}_{3}\right)$
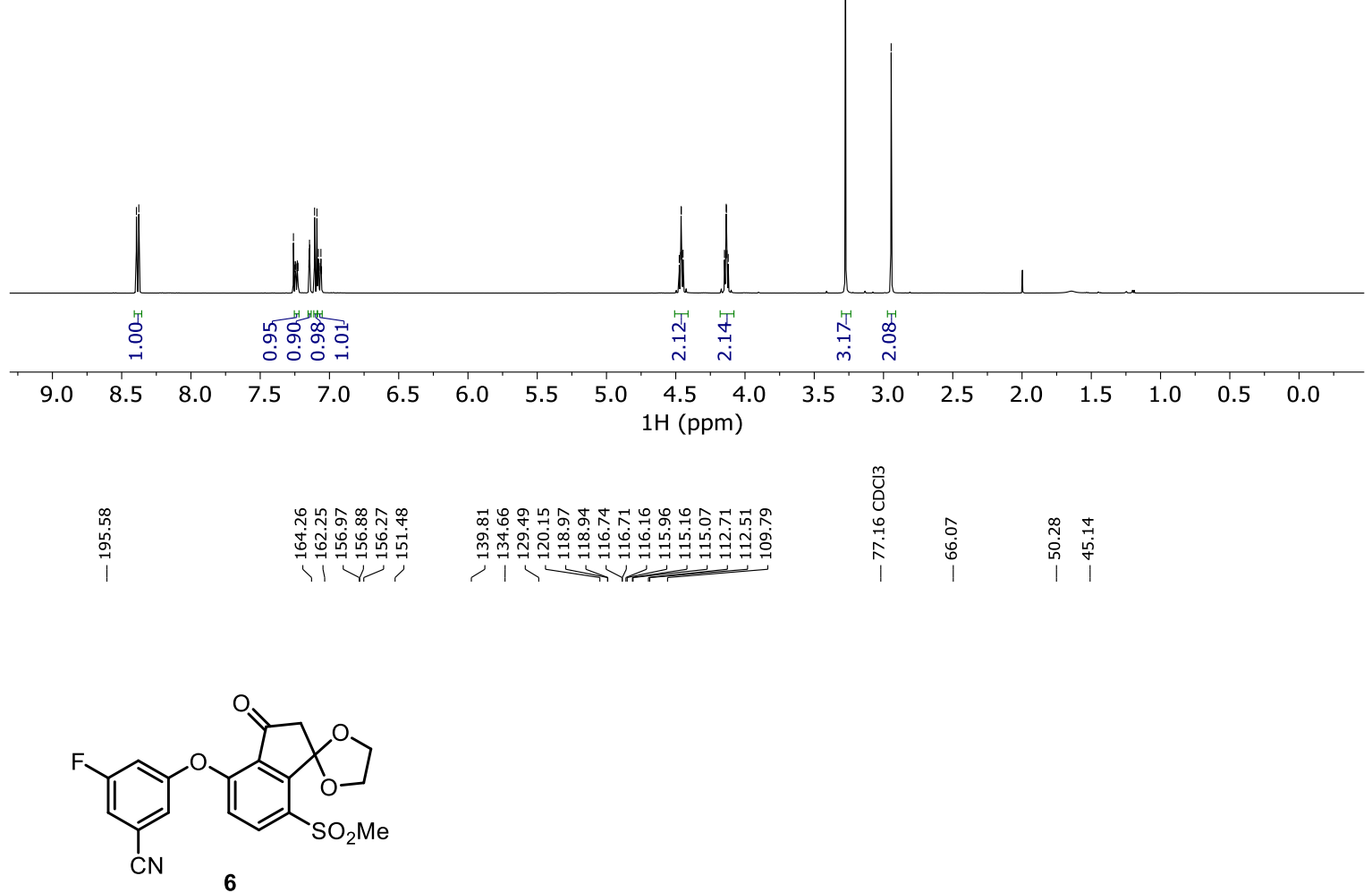

${ }^{13} \mathrm{C}\left\{{ }^{1} \mathrm{H}\right\} \operatorname{NMR}\left(126 \mathrm{MHz}, \mathrm{CDCl}_{3}\right)$

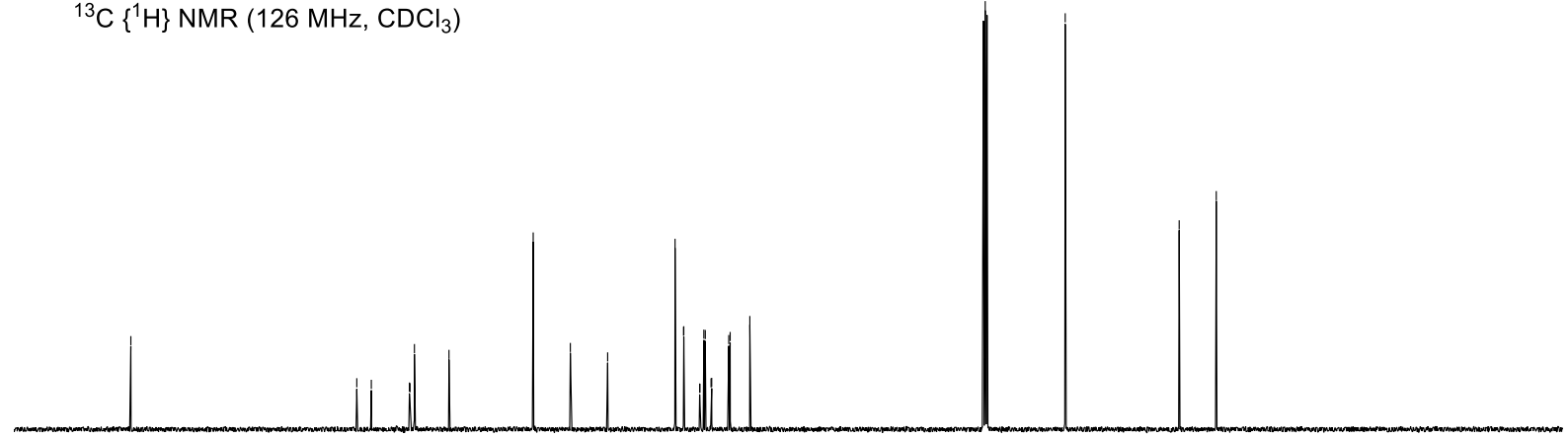

$\begin{array}{llllllllllllllllllll}210 & 200 & 190 & 180 & 170 & 160 & 150 & 140 & 130 & 120 & 110 & 100 \\ 13 C & 90 & 80 & 70 & 60 & 50 & 40 & 30 & 20 & 10 & 0\end{array}$ 

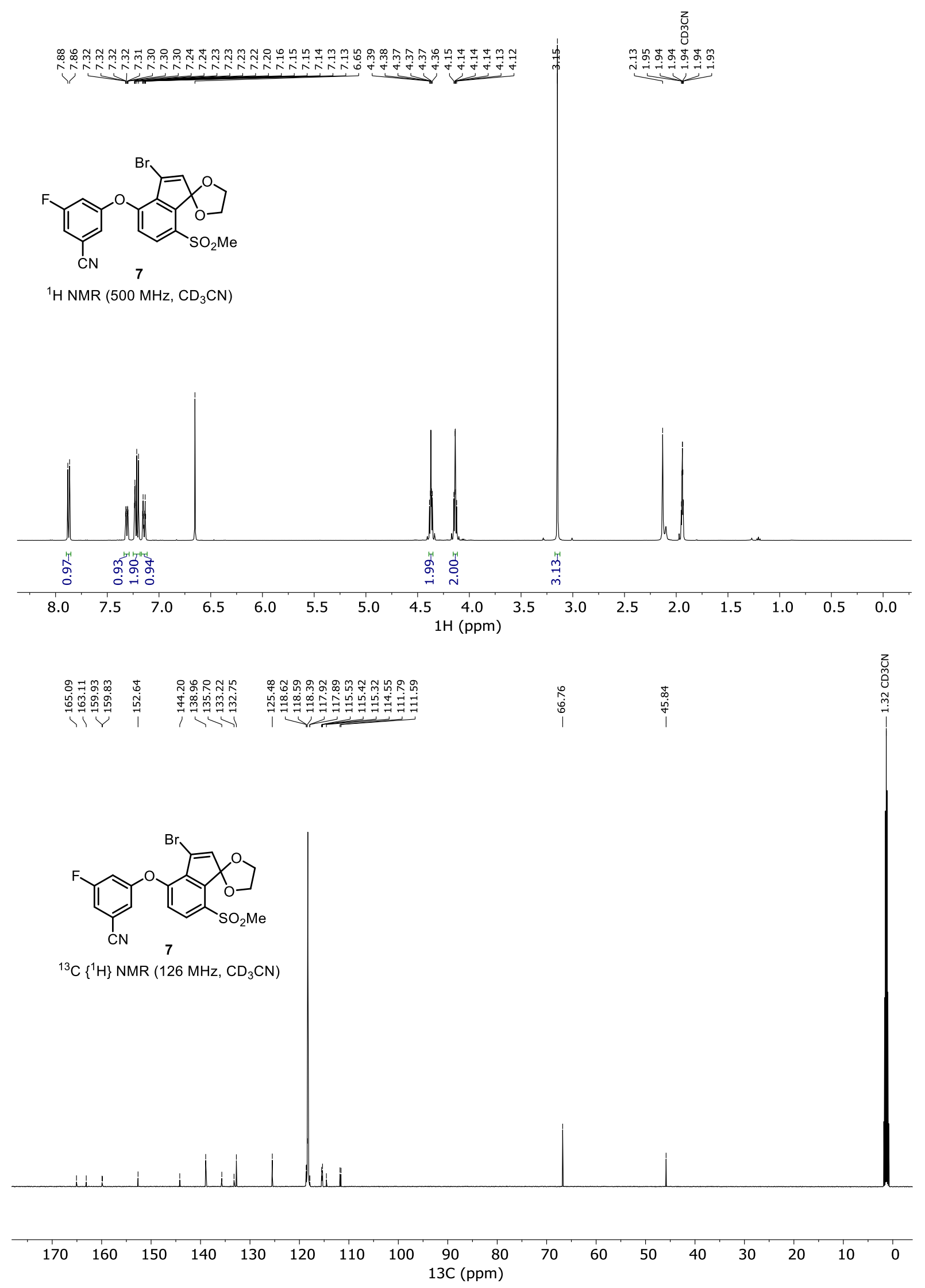

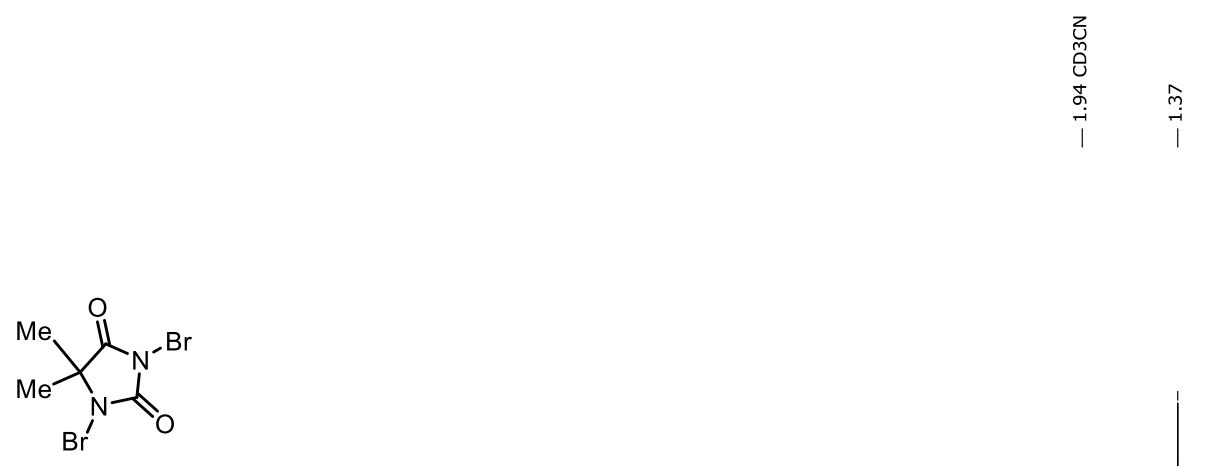

$2 a$

${ }^{1} \mathrm{H}$ NMR (599 MHz, CD ${ }_{3} \mathrm{CN}$ )
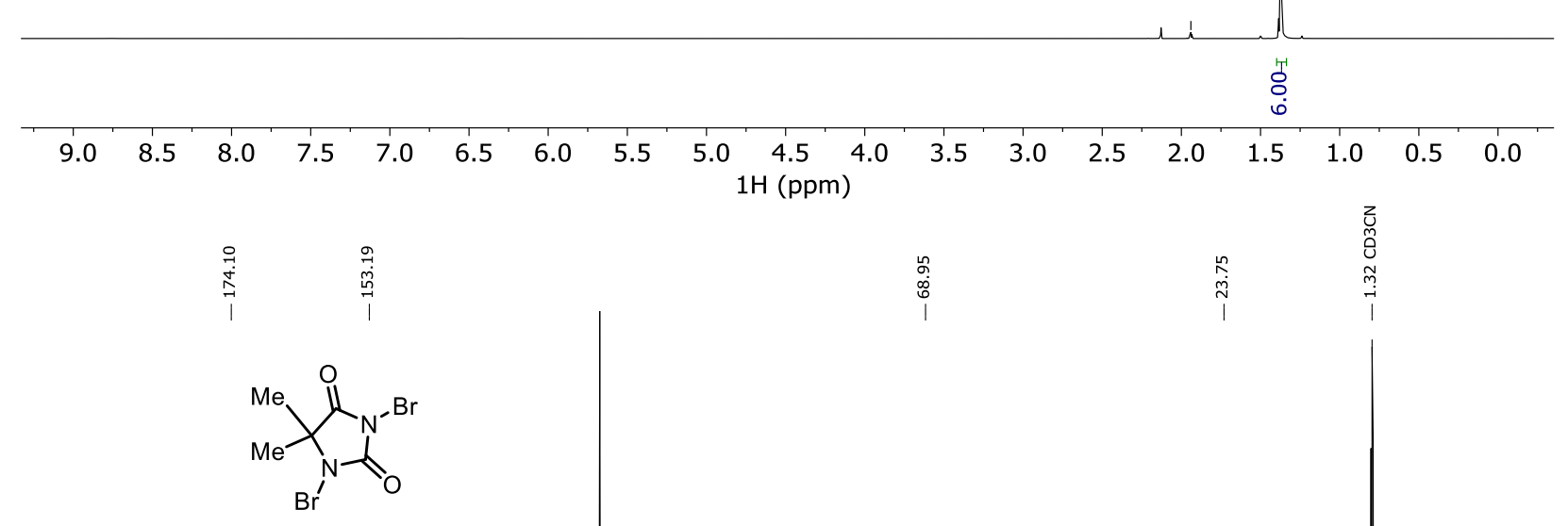

$2 \mathbf{a}$

${ }^{13} \mathrm{C}\left\{{ }^{1} \mathrm{H}\right\}$ NMR $\left(151 \mathrm{MHz}, \mathrm{CD}_{3} \mathrm{CN}\right)$

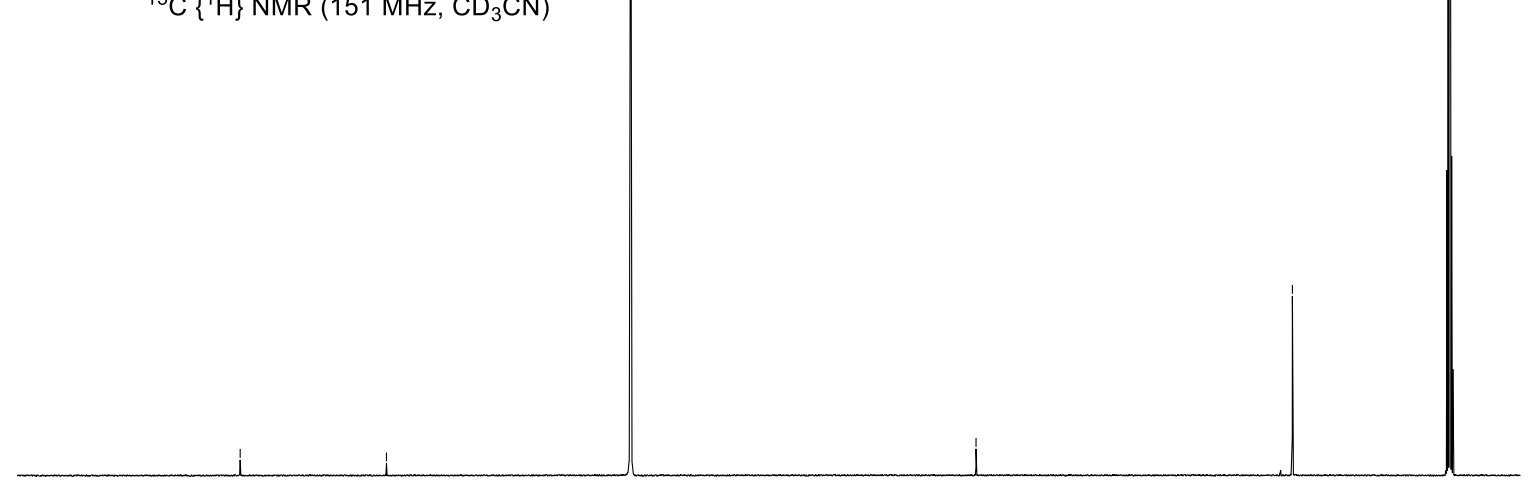

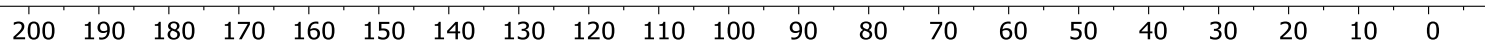
$13 \mathrm{C}(\mathrm{ppm})$ 


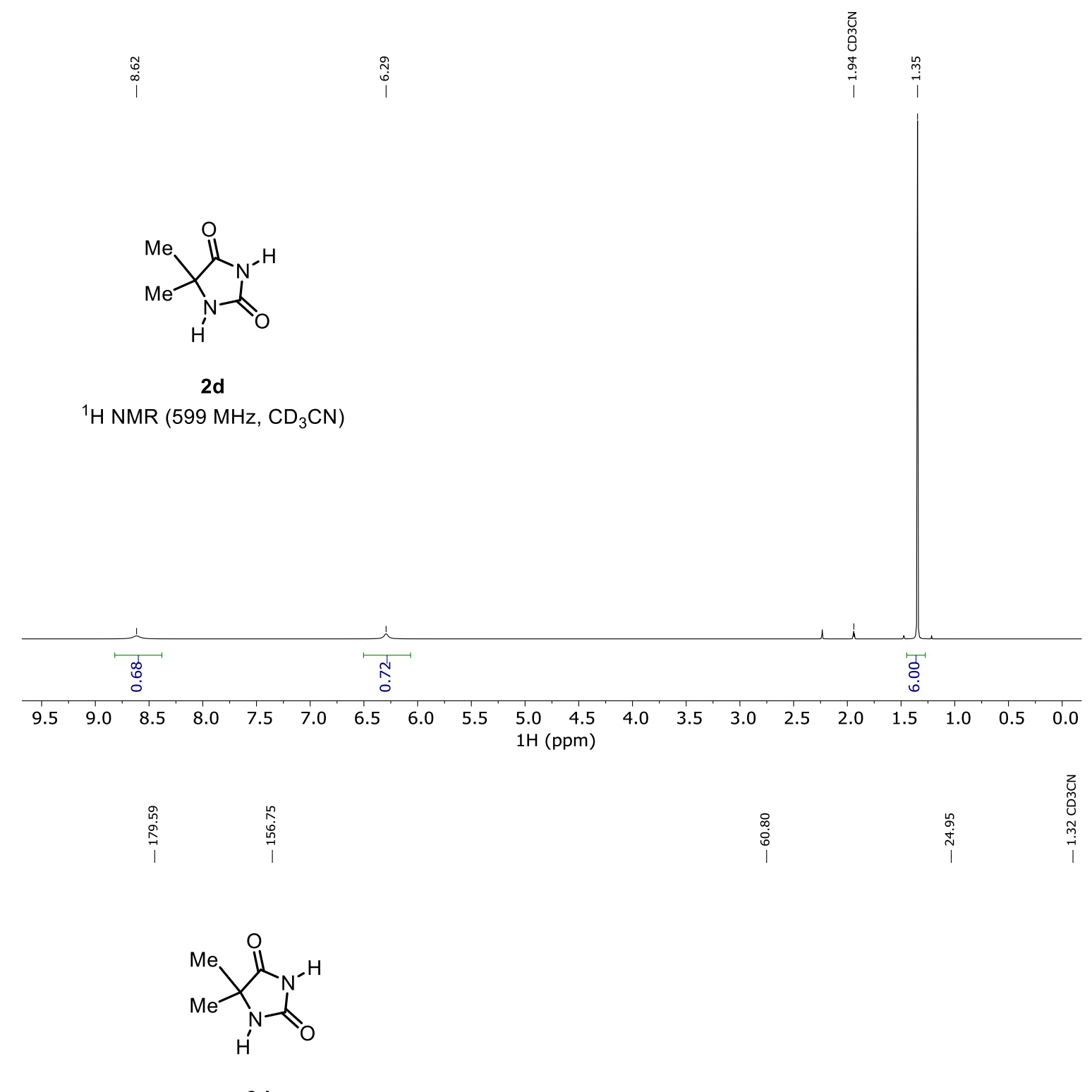

2d

${ }^{13} \mathrm{C}\left\{{ }^{1} \mathrm{H}\right\} \operatorname{NMR}\left(151 \mathrm{MHz}, \mathrm{CD}_{3} \mathrm{CN}\right)$

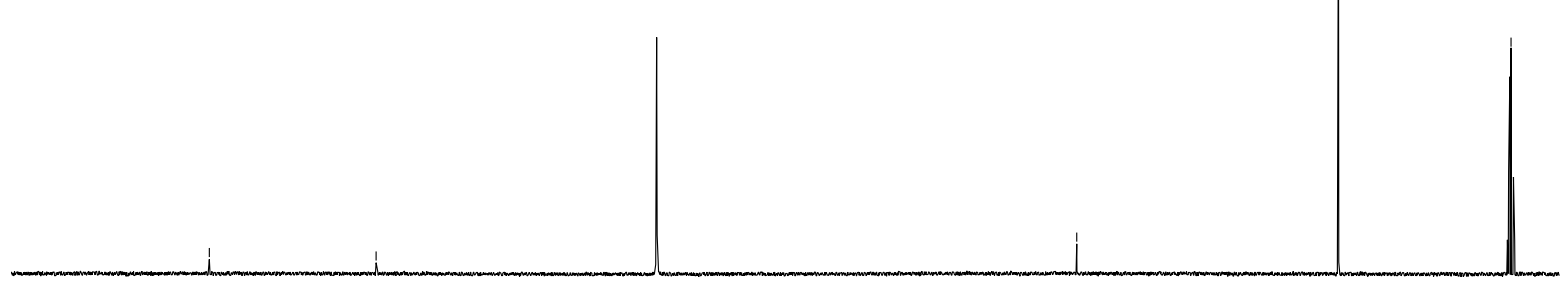

$\begin{array}{lllllllllllllllllllll}200 & 190 & 180 & 170 & 160 & 150 & 140 & 130 & 120 & 110 & 100 & 90 & 80 & 70 & 60 & 50 & 40 & 30 & 20 & 10 & 0\end{array}$ $13 \mathrm{C}(\mathrm{ppm})$ 
$\mathbf{2 b}$ and $\mathbf{2 c}$ could not be isolated; their structure elucidation and characterization were perfomed on a mixture of $\mathbf{2 a}, \mathbf{2 b}, \mathbf{2 c}$ and $\mathbf{2 d}$

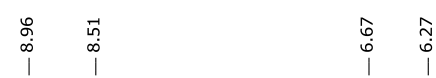<smiles>CC1(C)C(=O)N(Br)C(=O)N1Br</smiles><smiles>CC1(C)[13C](=O)N[13C](=[18O])N1Br</smiles>

$46 \quad 26$<smiles>CC1(C)NC(=O)NC1=O</smiles><smiles>[B]N1C(=O)NC(C)(C)C1=O</smiles>

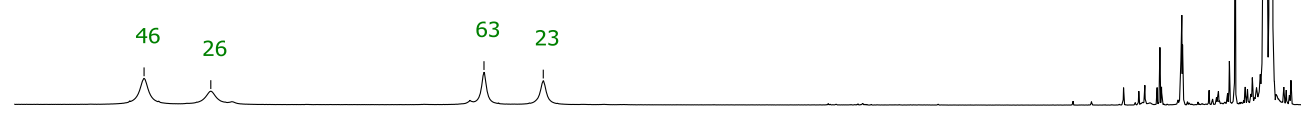
$1 \mathrm{H}$ (ppm)

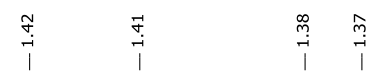<smiles>CC1(C)C(=O)N(Br)[R](=O)N1Br</smiles><smiles>CC1(C)NC(=O)NC1=O</smiles>

$4,5 \quad 24,25$<smiles>CN1C(=O)NC(=O)N([18O])C1(C)C</smiles><smiles>CC1(C)NC(=O)N([10B]=O)C1=O</smiles>

64,65

$\begin{array}{llllllllllllllllllllllll}1.53 & 1.52 & 1.51 & 1.50 & 1.49 & 1.48 & 1.47 & 1.46 & 1.45 & 1.44 & 1.43 & 1.42 & 1.41 & 1.40 & 1.39 & 1.38 & 1.37 & 1.36 & 1.35 & 1.34 & 1.33\end{array}$ $1 \mathrm{H}(\mathrm{ppm})$ 

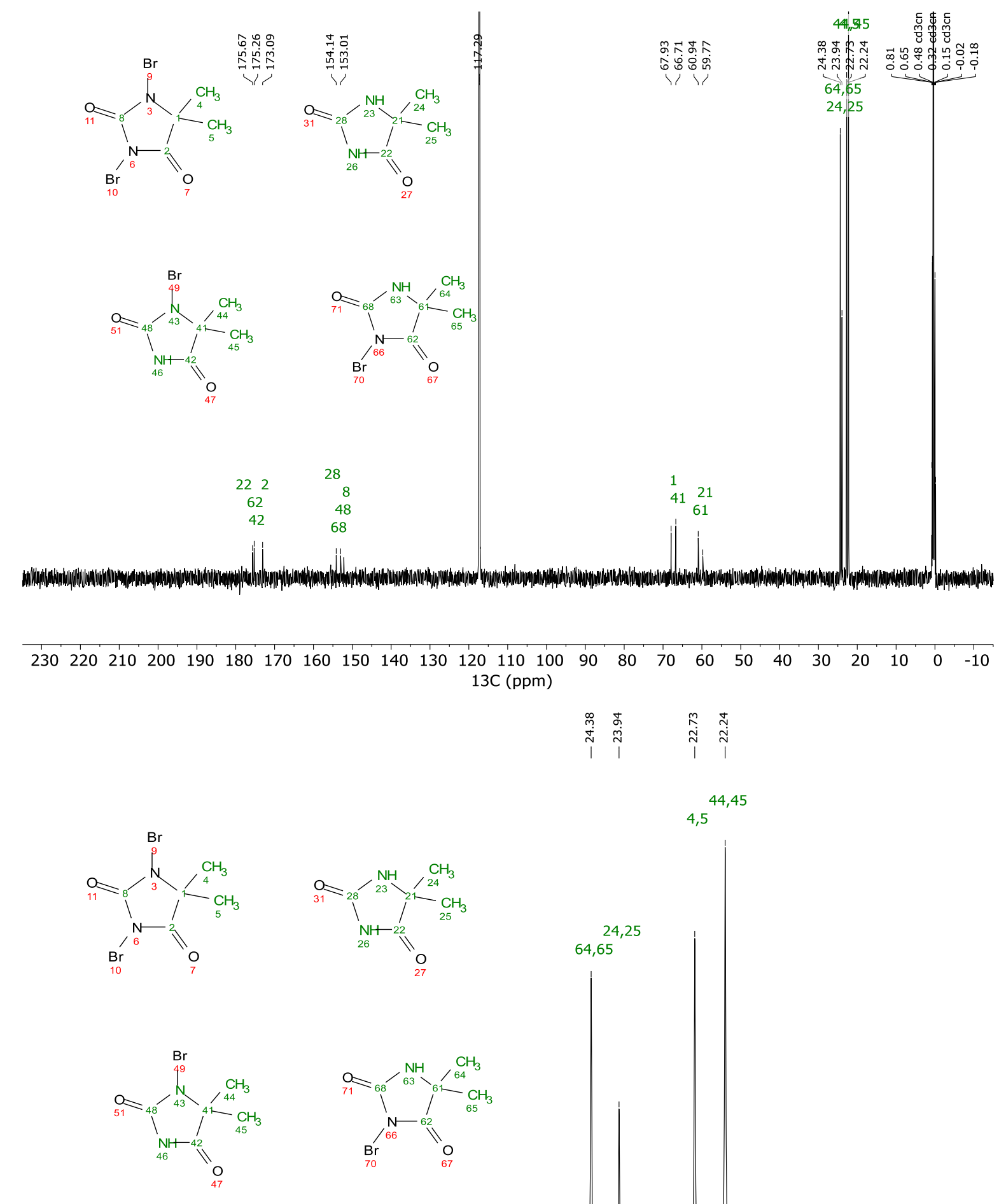

$$
4,5^{44,45}
$$

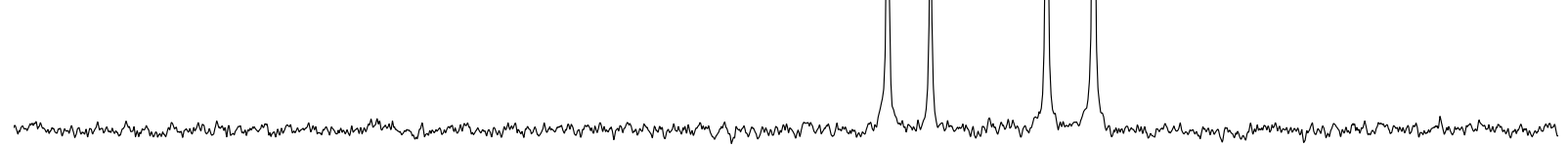

$\begin{array}{lllllllllllllll}33 & 32 & 31 & 30 & 29 & 28 & 27 & \begin{array}{c}26 \\ 13 \mathrm{C}(\mathrm{ppm})\end{array} & 24 & 23 & 22 & 21 & 20 & 19 & 18\end{array}$




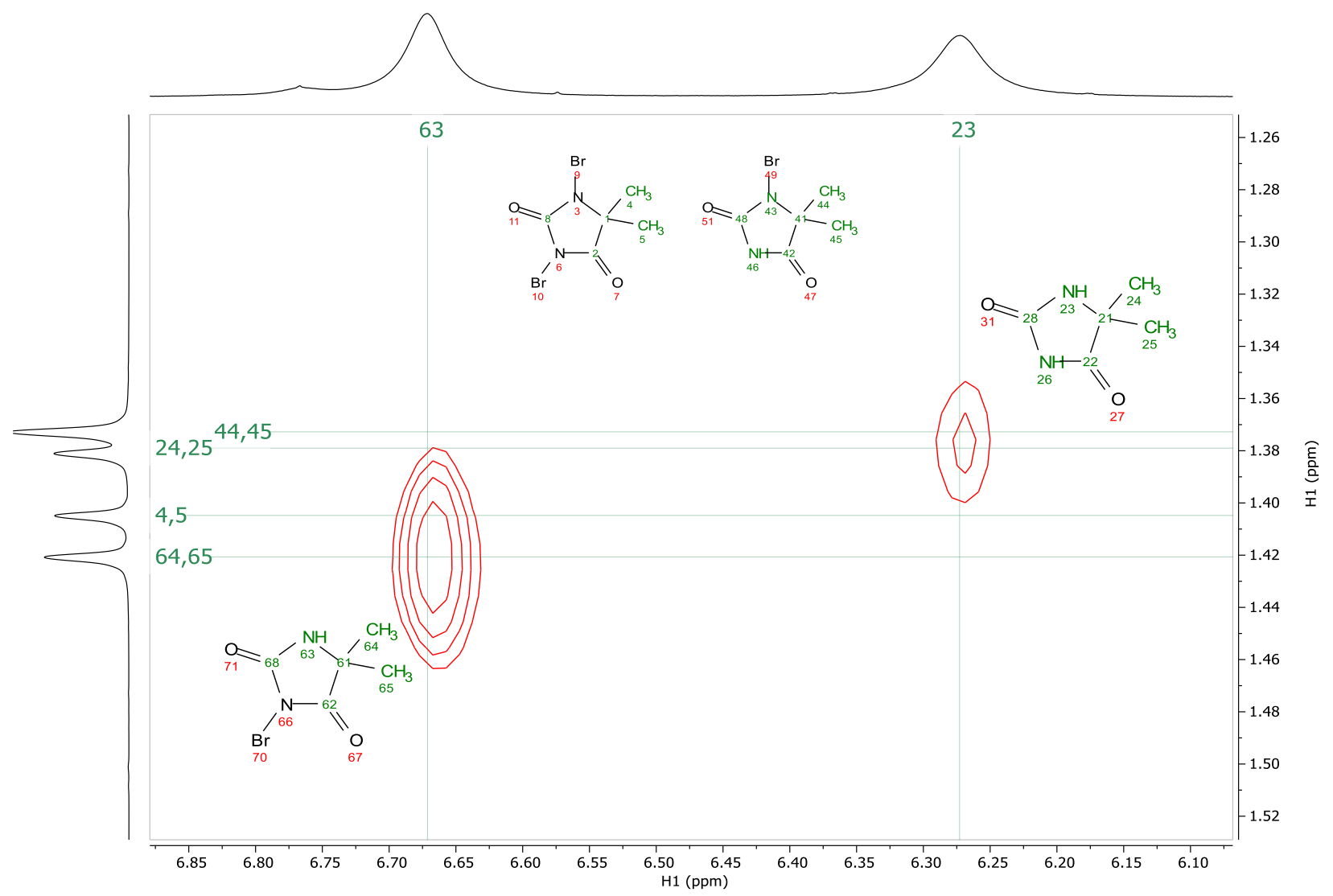

Figure S19. Key NOESY correlations used to unambiguously assign $\mathbf{2 b}$ and $\mathbf{2 c}$. $\mathbf{2 b}$ yields an NOE cross-peak between the amide and the methyl resonances, while $\mathbf{2 c}$ does not because the amide hydrogen is too far spatially from its methyl groups. $\mathbf{2 d}$ that is also present in the mixture yields a corresponding NOE cross-peak between the amide and the methyl resonances, similar that that of $\mathbf{2 b}$. NOESY spectrum was acquired on Varian Inova $500 \mathrm{MHz}$ instrument equipped with the IDX probe, with spectral width of $5100 \mathrm{~Hz}$ in both dimensions, mixing time of $400 \mathrm{~ms}, 4$ transients and 180 hypercomplex points in the indirect dimension. 